\title{
Toxic dinoflagellate blooms of Gymnodinium catenatum and their cysts in Taiwan Strait and their relationship to global populations
}

\author{
Minlu Liu ${ }^{\mathrm{a}}$, Haifeng $\mathrm{Gu}^{\mathrm{a}, \mathrm{b}, *}$, Bernd Krock ${ }^{\mathrm{c}}$, Zhaohe Luo ${ }^{\mathrm{a}}$, Yubo Zhang ${ }^{\mathrm{d}}$ \\ ${ }^{a}$ Third Institute of Oceanography, Ministry of Natural Resources, Xiamen 361005, China \\ ${ }^{\mathrm{b}}$ School of Marine Sciences, Nanjing University of Information Science and Technology, Nanjing 210044, China \\ ${ }^{c}$ Alfred Wegener Institut-Helmholtz Zentrum für Polar- und Meeresforschung, Am Handelshafen 12, D-27570 Bremerhaven, Germany \\ ${ }^{\mathrm{d}}$ Department of Marine Biology, Ocean University of China, Qingdao 266003, China
}

\section{A R T I C L E I N F O}

\section{Keywords:}

Blooms

Ecotype

Growth

Hydroxybenzoate toxins

Paralytic shellfish toxins

\begin{abstract}
A B S T R A C T
Gymnodinium catenatum is able to produce paralytic shellfish toxins (PSTs) and was responsible for a massive bloom in the Taiwan Strait, East China Sea, in June 2017, which resulted in serious human poisoning and economic losses. To understand the origin of the bloom and determine the potential for blooms in subsequent years, water and sediment samples collected in the Taiwan Strait from 2016 to 2019 were analyzed for cells and cysts using light microscopy (LM) and/or quantitative polymerase chain reaction (qPCR). The morphology of both cells and cysts from the field and cultures was examined with LM and scanning electron microscopy (SEM). Large subunit (LSU) and/or internal transcribed spacer (ITS)-5.8S rRNA gene sequences were obtained in 13 isolates from bloom samples and five strains from cysts. In addition, cells of strains TIO523 and GCLY02 (from the Taiwan Strait and Yellow Sea of China, respectively) were subjected to growth experiments, and cysts from the field were used for germination experiments under various temperatures. Our strains shared identical LSU and ITS-5.8S rRNA gene sequences with those from other parts of the world, and therefore belonged to a global population. A low abundance of $G$. catenatum cells were detected during most of the sampling period, but a small bloom was encountered in Quanzhou on June 8, 2018. Few cysts were observed in 2016 but a marked increase was observed after the bloom in 2017, with a highest density of 689 cysts $\mathrm{cm}^{-3}$. Cysts germinated at temperatures between 14 and $23{ }^{\circ} \mathrm{C}$ with a final germination rate over 93\%. Strains TIO523 and GCLY02 displayed growth at temperatures between 17 and $26^{\circ} \mathrm{C}$ and 14 and $26^{\circ} \mathrm{C}$, respectively, with both strains displaying the highest growth rate of ca. 0.5 divisions $\mathrm{d}^{-1}$ at $23^{\circ} \mathrm{C}$. The PSTs of the three strains and cysts from the sediments were analyzed by liquid chromatography with tandem mass spectrometry (LC-MS/MS). All strains were able to produce PSTs, which were dominated by N-sulfocarbamoyl C toxins (C1/2, 53.0-143.5 pg cell ${ }^{-1}$ ) and decarbamoyl gonyautoxins (dcGTX2/3, 26.7-52.1 pg cell ${ }^{-1}$ ), although they were not detected in cysts. However, hydroxybenzoyl (GC) toxins were detected in both cells and cysts. Our results suggested that the population in the Taiwan Strait belonged to a warm water ecotype and has a unique toxin profile. Our results also suggested that the persistence of cells in the water column may have initiated the bloom.
\end{abstract}

\section{Introduction}

The athecate dinoflagellate Gymnodinium catenatum was originally described from a bloom sample collected in the Gulf of California in the spring of 1939 (Graham, 1943). It was characterized by the formation of long chains of as many as 29 cells, but its detailed morphology was not clarified until Morey-Gaines (1982) revealed the loop shaped apical groove using scanning electron microscopy (SEM). Later, the ultrastructure of $G$. catenatum was reported and its taxonomic affinity with Gymnodiniales was confirmed (Rees and Hallegraeff, 1991).
Gymnodinium catenatum fits the emended description of Gymnodinium (Daugbjerg et al., 2000), but it is distant from the type species of Gymnodinium in terms of its molecular phylogeny (Luo et al., 2018).

A spherical, microreticulate cyst is produced by $G$. catenatum (Anderson et al., 1988), but later two other species, Gymnodinium nolleri and Gymnodinium microreticulatum, were reported to also produce similar microreticulate cysts (Bolch et al., 1999; Ellegaard and Moestrup, 1999). However, the motile cells of G. nolleri and G. microreticulatum do not form chains and their cysts are much smaller than those of $G$. catenatum and importantly those latter two taxa do not

\footnotetext{
* Corresponding author at: Third Institute of Oceanography, Ministry of Natural Resources, Xiamen 361005, China.

E-mail address: guhaifeng@tio.org.cn (H. Gu).
} 
produce toxins (Bolch et al., 1999). Microreticulate cysts were also generated by Gymnodinium trapeziforme and Gymnodinium inusitatum, but these cysts are elongated and irregular, and corresponding cells do not form long chains (Attaran-Fariman et al., 2007; Gu et al., 2013). The life cycle of $G$. catenatum was reported to be heterothallic, i.e., compatible strains of the opposite mating type are required for sexual reproduction, and a short dormancy period of two weeks was reported in this species (Blackburn et al., 1989; Figueroa et al., 2006).

The apparent cosmopolitan species Gymnodinium catenatum has been reported in warm temperate and tropical waters with an increasing frequency (Band-Schmidt et al., 2010; Hallegraeff et al., 2012), but it is typically present as isolated populations restricted to particular coastal areas (Bolch and Reynolds, 2002). Natural (e.g., currents, unusual climatic conditions, upwelling) and human-mediated (e.g., ballast water/sediment discharge) dispersions of $G$. catenatum have been reported (McMinn et al., 1997; Hallegraeff and Fraga, 1998; Blackburn et al., 2001; Amorim and Dale, 2006). Gymnodinium catenatum is not likely to spread naturally throughout oceans because it is an obligate coastal species, which requires particular nutrients from land runoff (Blackburn et al., 1989).

Molecular sequences of $G$. catenatum are rather conserved. All strains of $G$. catenatum share identical internal transcribed spacer (ITS)5.8S rRNA gene sequences, but display a single nucleotide polymorphism (SNP) at the 5th base of the 5.8S rRNA gene revealing two ribotypes, carrying either a thymidine (T-gene) or a cytosine (C-gene) (Bolch and De Salas, 2007). Later, two SNPs with guanine/adenine (R) overlaps were detected at positions 57 and 117 of the ITS1 region from Portuguese strains, which belonged to the C-gene ribotype (Silva et al., 2015). A large subunit (LSU) RNA gene sequence comparison also revealed that all strains of $G$. catenatum shared identical sequences except those from Bahía Concepción, Mexico, which had cytosine instead of guanine at position 453 (Band-Schmidt et al., 2008).

In contrast to the conserved molecular sequences, $G$. catenatum strains produce a wide variety of paralytic shellfish toxins (PSTs) profiles. The relationship between $G$. catenatum and paralytic shellfish poisoning was firstly found in Mexico in 1979 (Morey-Gaines, 1982), but the PSTs were not confirmed until an Australian strain was examined with high performance liquid chromatography (HPLC) (Oshima et al., 1987). Gymnodinium catenatum is now known to produce saxitoxin (STX), decarbamoyl saxitoxin (dcSTX), N-sulfocarbamoyl gonyautoxins (GTX1-GTX4) and the less toxic N-sulfocarbamoyl-11-hydroxysulfate B- and C-toxins (B1, B2, C1-C4), deoxy-decarbamoyl saxitoxin (doSTX), deoxy-decarbamoyl gonyautoxin 3 (doGTX3), and hydroxybenoyl PST derivatives (GC toxins) (Negri et al., 2007; Bustillos-Guzmán et al., 2015; Durán-Riveroll et al., 2017). The relative abundance of PSTs was found to differ among strains from different geographic origins (Oshima et al., 1992; Negri et al., 2001; Park et al., 2004; Negri et al., 2007), and may therefore be a useful marker to differentiate different populations.

Most reported blooms of $G$. catenatum occurred at temperatures below $18^{\circ} \mathrm{C}$, e.g., in the Gulf of California (Graham, 1943), Mazatlán, Sinaloa, Mexico (Morey-Gaines, 1982), southern Tasmanian estuaries of Australia (Hallegraeff et al., 1988), and Rías Baixas of Galicia, Spain (Figueroa et al., 2008), but some blooms have occurred at temperatures above $26{ }^{\circ} \mathrm{C}$, e.g., in Manila Bay, The Philippines (Corrales et al., 1996) and Singapore (Holmes et al., 2002). The relationship between $G$. catenatum cysts in the sediment and the breakout of blooms has been investigated in coastal areas of America, Australia and Europe (Hallegraeff et al., 1995; Bravo and Ramilo, 1999; Moita and Amorim, 2001; Flores-Trujillo et al., 2009). It is generally agreed that G. catenatum cysts play an important role in geographical dispersion, but cyst germination is not sufficient to develop into blooms (Bolch and De Salas, 2007). Instead, environmental factors such as temperature, nutrient supply or upwelling are probably the major constraints on the success of blooms (Bravo and Anderson, 1994; Hallegraeff et al., 1995; Bravo et al., 2010).
Gymnodinium catenatum cysts have been reported along the Chinese coast (Qi et al., 1996; Gu et al., 2013), but vegetative cells have rarely been reported in the South China Sea (Lu and Hodgkiss, 2004) and Yellow Sea (Jiao et al., 2010). Gymnodinium catenatum strains from Hong Kong and the Yellow Sea have a C-gene type in the 5.8S rRNA gene and thus belong to the global population (Bolch and De Salas, 2007; Gu et al., 2013). These Chinese strains also have similar toxin profiles, dominated by $\mathrm{C} 1-\mathrm{C} 4$, with an abundance of GC toxin (Negri et al., 2007; Gu et al., 2013). A massive G. catenatum bloom occurred in the Taiwan Strait in June 2017, causing serious paralytic shellfish poisoning events and economic losses (Chen, 2018). To understand the mechanism of the G. catenatum bloom occurrence, the coupling of cysts and cells was investigated in the Taiwan Strait using light microscopy (LM), a quantitative polymerase chain reaction (qPCR) and germination experiments. LSU and ITS-5.8S rRNA gene sequences were obtained from isolated cells from the bloom samples and established strains. Three strains and cysts from the field were subjected to a PST toxin analysis using liquid chromatography with tandem mass spectrometry (LC-MS/MS).

\section{Materials and methods}

\subsection{Sample collection and treatment}

Two bloom samples of $G$. catenatum were collected on June 9, 2017 and June 8,2018 , respectively (Table S1). The bloom samples were brought back to lab for morphological and molecular examination. A fraction of these samples were fixed with $0.4 \%$ Lugol's solution (Andersen and Throndsen, 2004) for cell counting. Cells (or chains) were isolated with a micropipette using an inverted Eclipse TS100 (Nikon, Tokyo, Japan) microscope for single cell PCR. In order to examine the seasonal appearance of $G$. catenatum, surface and bottom water samples (10, 15 and $20 \mathrm{~m}$ deep) were collected monthly at three stations in Xiamen Bay between December 2017 and August 2019 (Fig. 1, Table S2). Two liters of seawater were filtered through $5 \mu \mathrm{m}$ pore-size polycarbonate filters (Millipore, Eschborn, Germany) and stored at $-20{ }^{\circ} \mathrm{C}$ for qPCR. Additionally two liters of seawater were concentrated using a net with a mesh of $20 \mu \mathrm{m}$ and fixed with $0.4 \%$ Lugol's solution for direct cell counting with the above microscope.

To understand the potential roles of cysts in initiation and termination of $G$. catenatum blooms, sediment samples were collected from 2016 to 2019 in Taiwan Strait, including Xiamen Bay (Fig. 1, Table S1). Sediment samples were collected using a core or box sampler. Only surface sediments $(0-2 \mathrm{~cm})$ were sliced off but in several stations of Xiamen Bay, 20-30 cm sediments were collected at $2 \mathrm{~cm}$ intervals. Sediments were stored at $4{ }^{\circ} \mathrm{C} .2 .5 \mathrm{~cm}^{3}$ of surface layer of all the sediment samples, and of each layer of two core samples, were processed for cyst enumeration. Cysts were extracted using a sodium polytungstate density gradient with a density of $1.4 \mathrm{~g} \mathrm{~cm}^{-3}$ (Bolch, 1997) for direct cyst counting with the above microscope. Cysts were individually isolated to 96 well plates filled with $300 \mu \mathrm{L}$ of f/2-Si medium (Guillard and Ryther, 1962) and incubated at $20^{\circ} \mathrm{C}, 90 \mu \mathrm{mol}$ photons $\mathrm{m}^{-2} \mathrm{~s}^{-1}$ under a 12: $12 \mathrm{~h}$ light: dark cycle for establishment of five strains (Table 1). Strains were maintained in $100 \mathrm{~mL}$ Erlenmeyer flasks under the same conditions described above.

\subsection{Light and scanning electron microscopy}

Live cells and cysts were examined and photographed using a Zeiss light microscope (Carl Zeiss, Göttingen, Germany) equipped with a Zeiss digital camera. The size of 33 cells from the bloom sample and 53 cells from culture, four newly formed and 26 mature cysts was measured using Axiovision (4.8.2 version) software at $\times 400$ magnification.

For scanning electron microscopy (SEM), cells and cysts from the bloom samples, cells of strain TIO523 and cysts from the sediment were fixed at final concentration of $1 \% \mathrm{OsO}_{4}$ for $20 \mathrm{~min}$. The supernatant was 


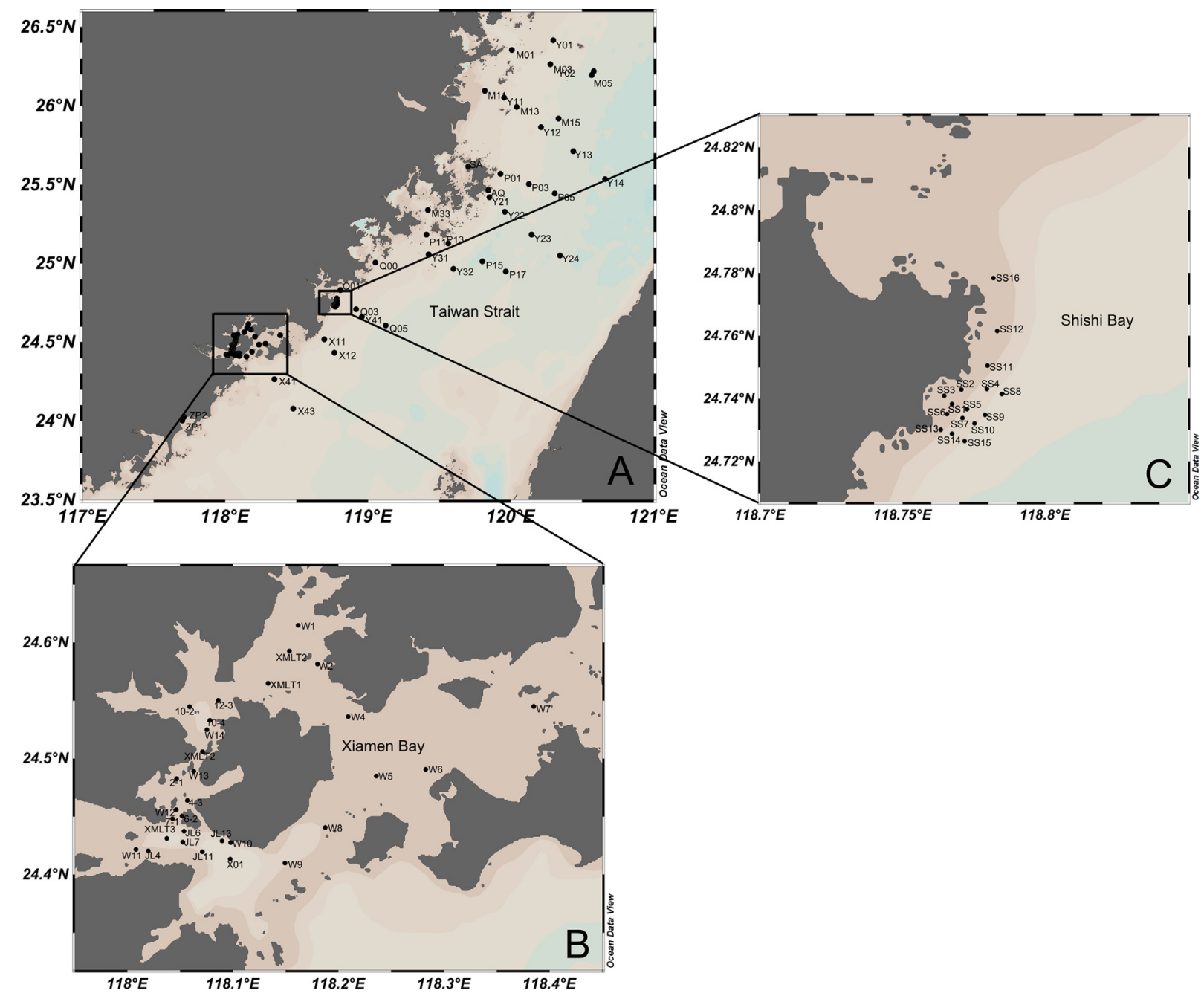

Fig. 1. Sampling area and locations in Taiwan Strait. (A) Overview of stations. (B) Detailed view of the stations in Xiamen Bay. (C) Detailed view of the stations in Quanzhou.

removed and the settled cells were transferred to a coverslip coated with poly-L-lysine (molecular weight 70,000-150,000). The cells attached to the cover slip were rinsed in Milli-Q water twice. The samples were then dehydrated in a graded ethanol series $(10,30,50,70,90$ and $3 \times$ in 100\%, $10 \mathrm{~min}$ at each step), critical point dried (K850 Critical Point Dryer, Quorum/Emitech, West Sussex, UK), sputter-coated with gold, and examined with a Zeiss (Carl Zeiss Inc., Oberkochen, Germany) scanning electron microscope.

\subsection{PCR amplifications and sequencing}

The molecular sequences of 13 isolates of $G$. catenatum collected from the bloom samples and five strains were examined (Table 1). Single chains were isolated from the bloom samples and available strains and washed several times with sterile distilled water and used for templates. PCR amplifications were carried out using $1 \times$ PCR buffer, $50 \mu \mathrm{M}$ dNTP mixture, $0.2 \mu \mathrm{M}$ of each primer, and $1 \mathrm{U}$ of ExTaq DNA Polymerase (Takara, Tokyo, Japan) in $50 \mu \mathrm{L}$ reactions. The LSU rRNA gene (D1-D6) was amplified using the primers D1R/28-1483R (Daugbjerg et al., 2000). ITS1-5.8S-ITS2 region was amplified using ITSA and ITSB primers (Adachi et al., 1996). The thermal cycle procedure was $4 \mathrm{~min}$ at $94{ }^{\circ} \mathrm{C}$, followed by 30 cycles of $1 \mathrm{~min}$ at $94{ }^{\circ} \mathrm{C}$, $1 \mathrm{~min}$ at $45{ }^{\circ} \mathrm{C}, 1 \mathrm{~min}$ at $72{ }^{\circ} \mathrm{C}$, and a final extension of $7 \mathrm{~min}$ at $72{ }^{\circ} \mathrm{C}$ with a Mastercycler (Eppendorf, Hamburg, Germany). The PCR product was purified using a DNA purification kit (Shengong, Shanghai, China) and sequenced directly in both directions on an ABI PRISM 3730XL (Applied Biosystems, Foster City, CA, USA) following the manufacturer's instructions. Sequences were deposited in GenBank with accession numbers MT659672 to MT659680 and MT659389 to MT659402.

\subsection{Quantitative PCR ( $q P C R)$}

Total environmental gDNAs of water samples were extracted using the Nucleospin soil kit (Macherey \& Nagel, Germany) according to the manufacturer's instructions. DNA extracts were analysed using the $G$. catenatum specific real-time PCR assay (Smith et al., 2014) on a CFX Connect $^{\mathrm{TM}}$ real-time PCR detection system (Bio-Rad, CA, USA). The primers (GC397-F and GC471-R) and probe (GC426-P) targeted the LSU rRNA gene and their specificity has been tested previously by Smith et al. (2014). The optimised assays consisted of a $20 \mu \mathrm{L}$ reaction containing $10 \mu \mathrm{L}$ of $2 \times$ Taqman Fast qPCR Master Mix (Sangon Biotech, Inc., Shanghai, China), $200 \mathrm{nM}$ of forward and reverse primers, $200 \mathrm{nM}$ of fluorescent probe, and $2 \mu \mathrm{L}$ of DNA template. Cycling conditions were as follows: $50{ }^{\circ} \mathrm{C}$ for $2 \mathrm{~min}, 95{ }^{\circ} \mathrm{C}$ for $2 \mathrm{~min}, 45$ cycles of $95{ }^{\circ} \mathrm{C}$ for $15 \mathrm{~s}$, and $60^{\circ} \mathrm{C}$ for $45 \mathrm{~s}$.

The sensitivity of the assay was evaluated with gDNA extracted from a low range of known cell concentrations (1, 3, 5 and 10 cells). Calibration curves were constructed using serial dilutions of a known concentration of both synthetic gene fragment and cells (Kon et al., 2015). Gene fragment of the LSU rRNA of $G$. catenatum flanked by both 


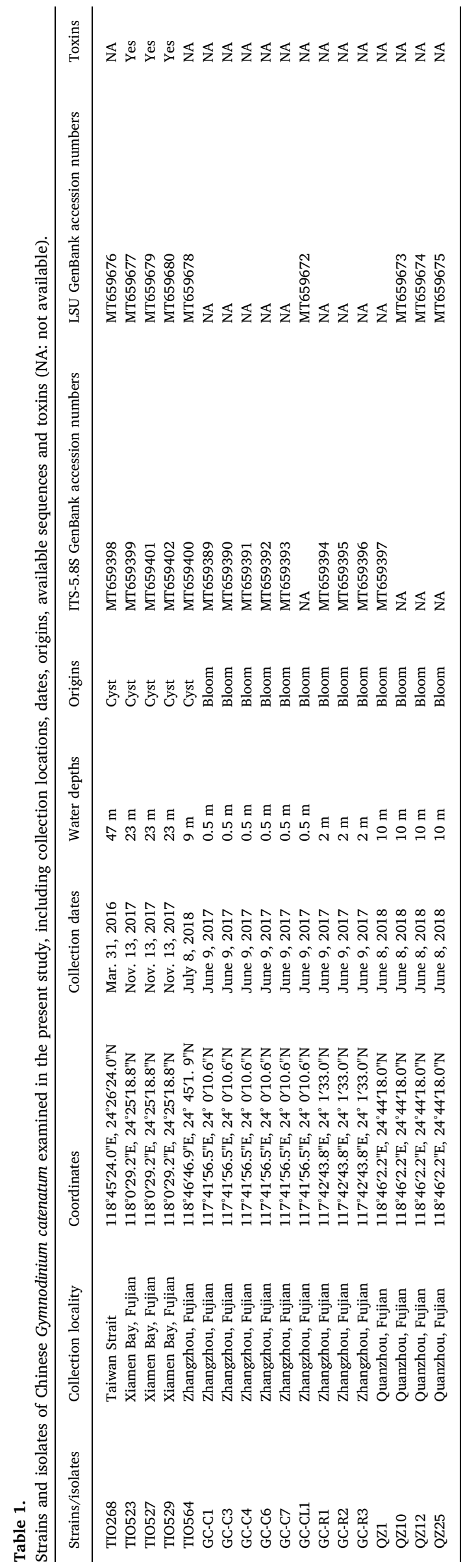

forward and reversed primers, with extra ten base pair (bp) at both ends was synthesized (Sangon Biotech, Inc., Shanghai, China). A linear regression was performed onto the calibration curve to determine the $R^{2}$ value and slope. Amplification efficiency (AE) was calculated as $\mathrm{AE}=[10(-1 /$ slope $)-1] \times 100 \%$. The extractable LSU rRNA gene copies per cell of $G$. catenatum were determined from samples with known cell number using the gene fragment calibration curve. After the mean extractable LSU rRNA gene copies per cell were confirmed, subsequent samples were examined by qPCR based on synthetic gene fragment as it was more stable for long-term preservation. All PCR reactions in this study were performed in triplicate and included no template control (NTC) and positive control (known concentration of synthetic gene fragment).

\subsection{Assessment of the qPCR assay}

Specificity of the assay has been tested in previous study via both cross-reactivity testing and in silico analysis using NCBI blast (Smith et al., 2014). The NTC included in each qPCR run showed no amplification. The gene-based calibration curve had a linear detection ranging over seven-orders of magnitude $\left(R^{2}=0.9995, \mathrm{AE}=94.6 \%\right.$; Fig. S1). The qPCR assay was able to detect as low as $10^{2}$ gene copies. The cell-based calibration curve was linear over seven-orders of magnitude $\left(R^{2}=0.9993 ; \mathrm{AE}=96.1 \%\right.$; Fig. S1). Evaluation of the assay sensitivity showed that our qPCR assay was able to detect consistent $\mathrm{Cq}$ from one $(\mathrm{Cq}=27.44 \pm 0.39)$, three $(\mathrm{Cq}=26.03 \pm 0.48)$, five $(\mathrm{Cq}=25.27 \pm 0.22)$ and $10(\mathrm{Cq}=24.24 \pm 0.27)$ target cells, respectively. Therefore, the minimum number of cells for a reliable quantification was determined to be one cell per reaction. The mean extractable LSU copy numbers per cell of $G$. catenatum in this study was $14,319 \pm 2237$ (slope $\pm \mathrm{SD})\left(R^{2}=0.9997, P<0.0001\right.$, Fig. S2). Cell densities estimated using the gene-based calibration curve showed a positive correlation with cell densities determined microscopically $\left(R^{2}=0.95, P<0.0001\right.$; Fig. S3).

\subsection{Germination experiment}

In order to determine the effect of temperatures on cyst germination, 46-89 cysts collected from Xiamen Bay on November 13, 2017 were individually isolated to 96 well plates filled with $300 \mu \mathrm{L}$ of f/2-Si medium and incubated at $11,14,17,20$ and $23{ }^{\circ} \mathrm{C}, 90 \mu \mathrm{mol}$ photons $\mathrm{m}^{-2} \mathrm{~s}^{-1}$ under a 12: $12 \mathrm{~h}$ light: dark cycle. Daily during 30 days cyst germination was registered. The experiment was performed from January 26, 2018 to April 6, 2018.

In order to understand the effect of storage on germination, samples collected from Xiamen Bay on March 15, 2018 were stored at $4{ }^{\circ} \mathrm{C}$ for two years. 90 cysts were individually isolated to 96 well plates filled with $300 \mu \mathrm{L}$ of $\mathrm{f} / 2$-Si medium at $23^{\circ} \mathrm{C}, 90 \mu \mathrm{mol}$ photons $\mathrm{m}^{-2} \mathrm{~s}^{-1}$ under a 12: $12 \mathrm{~h}$ light: dark cycle, and checked daily during 10 days for germination.

\subsection{Effect of temperature on growth}

The strain TIO523 from Taiwan Strait and strain GCLY02 from Yellow Sea (Gu et al., 2013) were subjected to different temperatures. Growth experiments at various temperatures $(14,17,20,23,26$, and $29{ }^{\circ} \mathrm{C}$ ) were conducted in triplicate using $50 \mathrm{~mL}$ Erlenmeyer flasks with $30 \mathrm{~mL} \mathrm{f} / 2$-Si medium and an initial cell density of 200 cells $\mathrm{mL}^{-1}$. Cultures were acclimated over a period of 15 days to neighboring temperatures successively, at steps no greater than $3{ }^{\circ} \mathrm{C}$ at a time. The light: dark cycle in all experiments was 12:12 h. Subsamples of $0.05 \mathrm{~mL}$ were removed from the culture at 2-day intervals and fixed in $0.4 \%$ Lugol's solution. Each subsample was transferred to a Sedgwick-Rafter chamber and a minimum of 200 cells per sample were counted. The growth rates in the exponential growth phase were calculated according to the method of Guillard (1973) by a least squares fit of a 

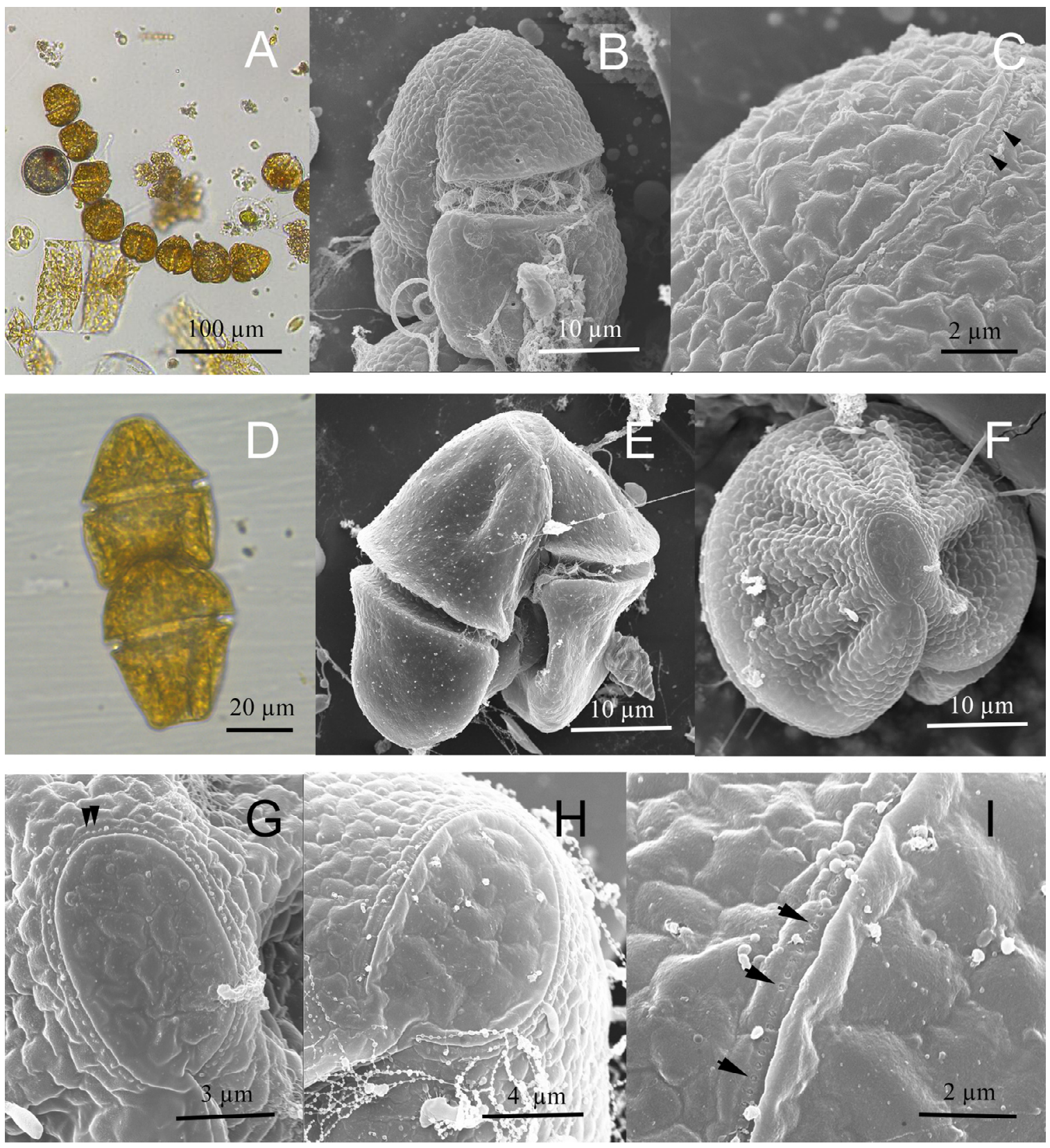

Fig. 2. LM and SEM of Gymnodinium catenatum cells. (A) Chain of cells in samples collected during the 2017 bloom with a newly formed cyst (LM); (B) Chain of cells in samples collected during the 2017 bloom (SEM). (C) Detail of ASC in the cell of B showing numerous knobs (arrowheads, SEM). (D) Chain of two cells in samples collected during the 2018 bloom (LM). (E). A cell of strain TIO523 in ventral view (SEM). (F). A cell of strain TIO523 in apical view (SEM). (G) Detail of apical structure complex (ASC) in the cell of F showing numerous knobs (arrowheads, SEM). (H, I) Detail of ASC in another cell showing numerous pores (arrows) from which small knobs emerge (SEM).

straight line to the data after logarithmic transformation.

\subsection{Paralytic shellfish toxins analysis}

Around 13,000 cysts were isolated from sediment collected in March 2018 in Xiamen Bay and approximately 70,000 cells of strains TIO523, TIO527 and TIO529 in exponential phase were collected by centrifugation. Algal pellets were transferred to $2 \mathrm{~mL}$ microcentrifuge tubes and stored at $-20{ }^{\circ} \mathrm{C}$ until analysis. Cell pellets were resuspended in $500 \mu \mathrm{L} 0.03 \mathrm{M}$ acetic acid and subsequently homogenized with $0.9 \mathrm{~g}$ of lysing matrix D by reciprocal shaking at maximum speed $\left(6.5 \mathrm{~m} \mathrm{~s}^{-1}\right)$ for $45 \mathrm{~s}$ in a Bio101 FastPrep instrument (Thermo Savant, Illkirch, France). After homogenization, samples were centrifuged at 16,100 $\times \mathrm{g}$ at $4{ }^{\circ} \mathrm{C}$ for $15 \mathrm{~min}$. The supernatants were transferred to spin-filters
(0.45 $\mu \mathrm{m}$ pore-size, Millipore Ultrafree, Eschborn, Germany) and centrifuged for $30 \mathrm{~s}$ at $800 \times \mathrm{g}$, followed by transfer to autosampler vials for LC-MS/MS analysis. Chromatographic separation was achieved on an Acquity UPLC Glycan BEH Amide column (130 ̊, $150 \mathrm{~mm} \times 2.1 \mathrm{~mm}, 1.7 \mu \mathrm{m}$, Waters, Eschborn, Germany) equipped with an in-line $0.2 \mu \mathrm{m}$ Acquity filter and thermostated at $60^{\circ} \mathrm{C}$ with an isocratic elution to $5 \mathrm{~min}$ with $98 \%$ eluent B followed by a linear gradient of $2.5 \mathrm{~min}$ to $50 \% \mathrm{~B}$ and $1.5 \mathrm{~min}$ isocratic elution. The flow rate was $0.4 \mathrm{~mL} \mathrm{~min}^{-1}$, and the injection volume was $2 \mu \mathrm{L}$. Mobile A consisted of water with $0.15 \%$ formic acid and $0.6 \%$ ammonia $(25 \%)$. Mobile B consisted water/acetonitrile (3:7, v/v) with $0.1 \%$ formic acid. Mass spectrometric experiments were performed in the selected reaction monitoring (SRM) mode on a Xevo TQ-XS triple quadrupole mass spectrometer equipped with a Z-Spray source (Waters, Eschborn, 

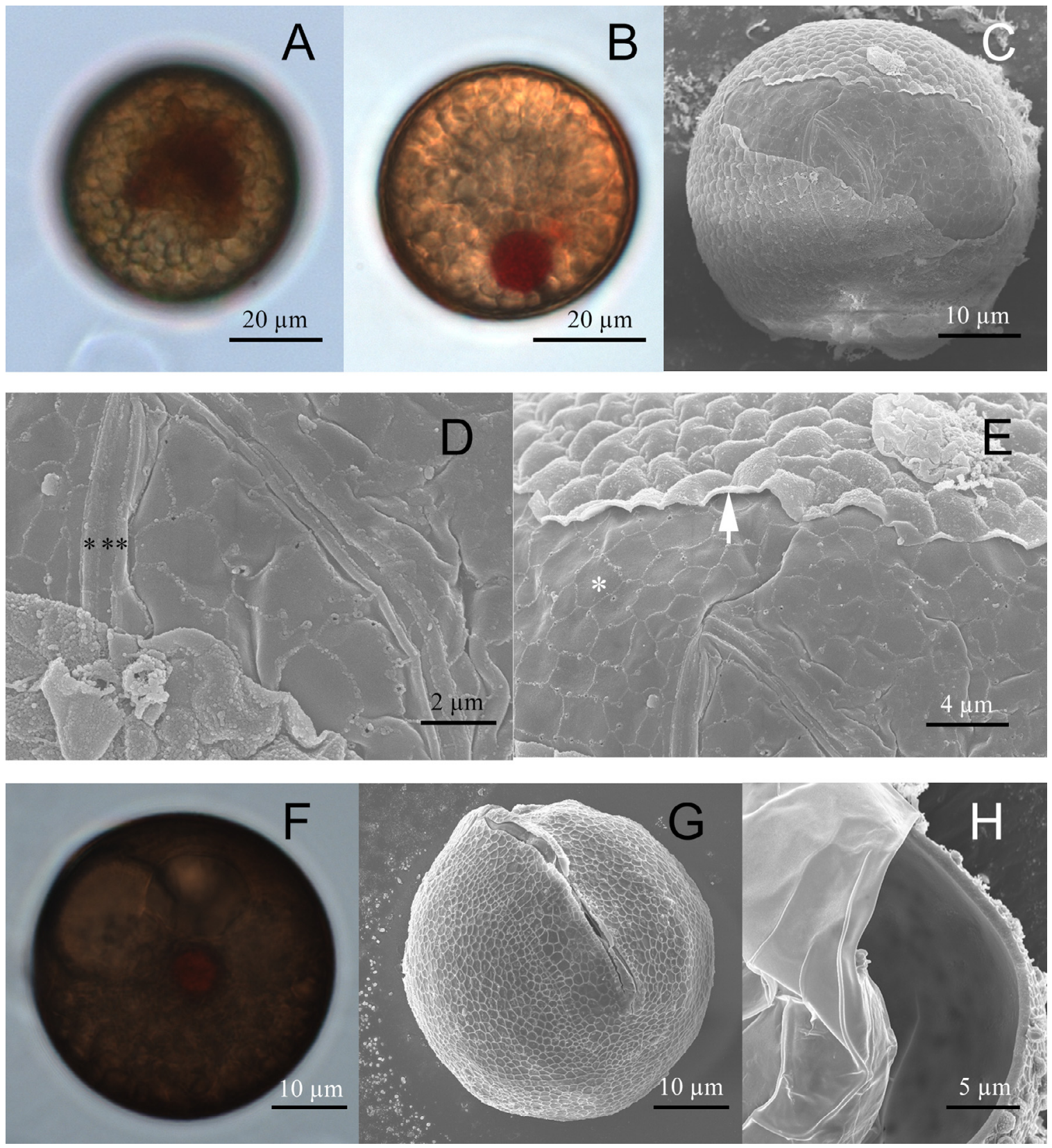

Fig. 3. LM and SEM of Gymnodinium catenatum cysts from the field. (A, B) Newly formed cysts from the 2017 bloom samples (LM). (C) A newly formed cyst showing two thin layers (SEM). (D) Detail of equivalent of ASC showing three elongated vesicles (*) in the newly formed cyst. (E) Detail of the outer wall (arrow) and inner wall $\left(^{*}\right)$ with microreticulations in the newly formed cyst (SEM). (F) A mature cyst collected in November 2017 (LM). (G) A mature cyst showing the microreticulations (SEM). (H). A broken cyst showing the thick wall (SEM).

Germany). Instrument parameters are given in table S3 and used mass transitions in Table S4. PSTs were quantified by external calibration with standard mix solutions of four concentration levels consisting of the following PSTs: STX, NEO, GTX2/3, GTX1/4, dcSTX, dcGTX2/3, B1, and $\mathrm{C} 1 / 2$. All individual standard solutions were purchased from the Certified Reference Materials Program (CRMP) of the Institute for Marine Biosciences, National Research Council (Halifax, Canada). GC toxins were only reported as absent or present due to the lack of available standards and their very different mass spectrometric behavior.

\section{Results}

\subsection{Morphology of G. catenatum cells and cysts}

Chains of 8-16 cells were dominant in the bloom samples on June 9, 2017 (Fig. 2A). Vegetative cells were from 30.0 to $51.8 \mu \mathrm{m}$ (mean $=38.5 \pm 5.4 \mu \mathrm{m}, n=33$ ) long and from 30.0 to $47.1 \mu \mathrm{m}$ (mean $=35.8 \pm 4.6 \mu \mathrm{m}, n=33$ ) wide. The epicone was conical whereas the hypocone was flattened (Fig. 2B). The sulcus extended into the epicone as a narrow furrow and widened towards the posterior end. There was a loop-shaped apical structure complex (ASC) that almost completely encircled the apex, which consisted of three elongated vesicles. There were numerous knobs in the middle of the elongated vesicles (Fig. 2C). Large cells, $56 \mu \mathrm{m}$ long, were observed in the bloom samples on June 8, 2018 (Fig. 2D). 
Gymnodinium catenatum cells (cells L-1) Nov. 2018

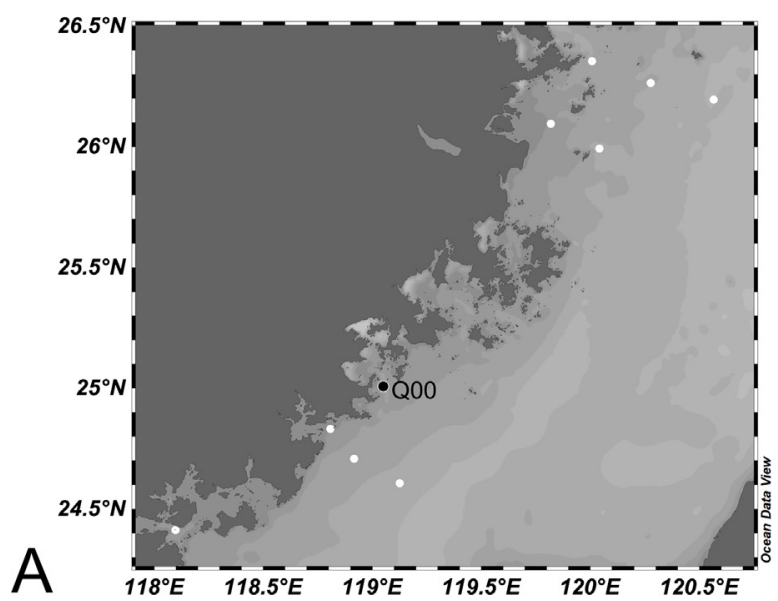

Gymnodinium catenatum cells (cells $L^{-1}$ ) July 2019

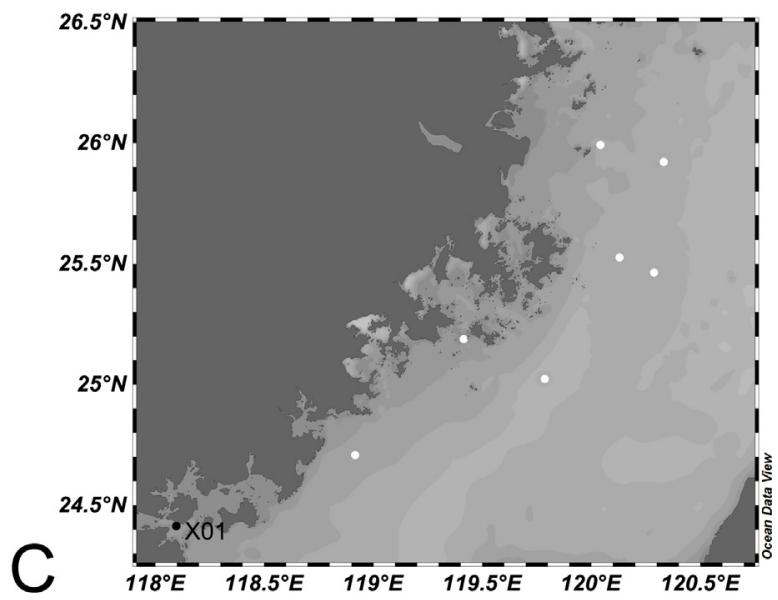

Gymnodinium catenatum cells (cells L-1) May 2019
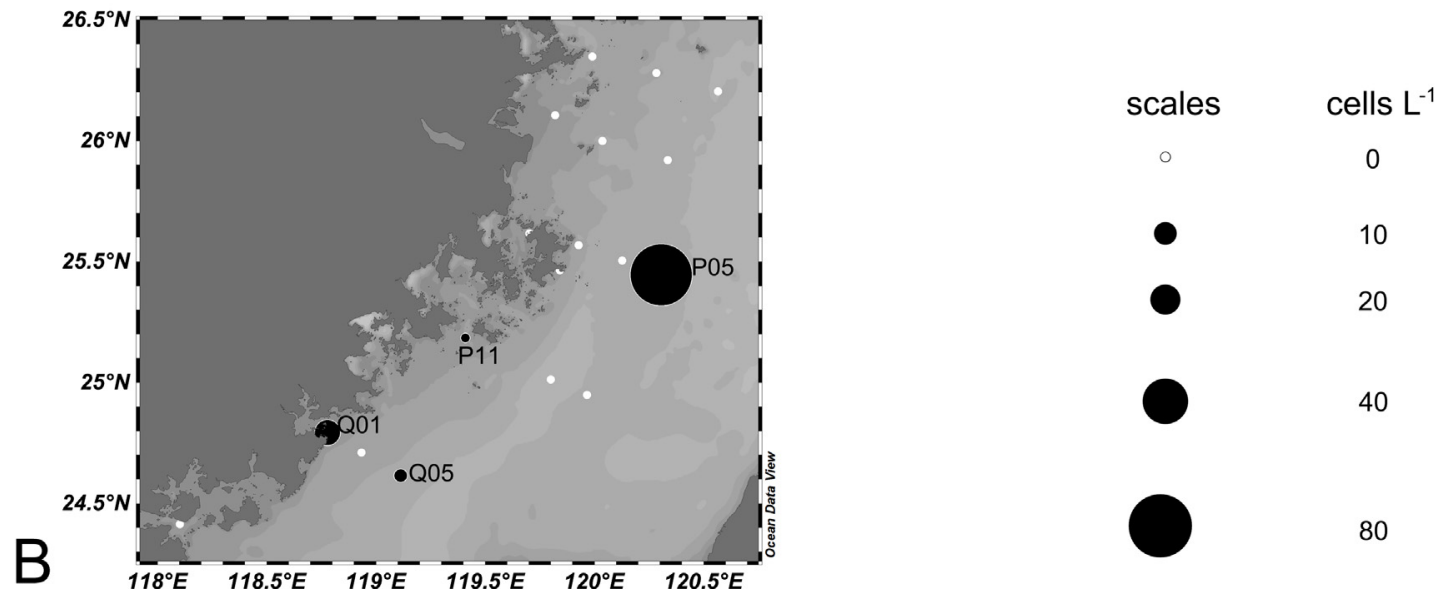

Fig. 4. Cell abundance of Gymnodinium catenatum determined by qPCR in water samples in Taiwan Strait in November 2018 , May 2019 and July 2019.

Cells in culture formed chains from 2 to 16 cells, and were morphologically identical to those from the bloom samples (Fig. 2E-H). Approximately 100 small knobs were present in the middle of the ASC, which emerged from a round pore approximately $120 \mathrm{~nm}$ in diameter (Fig. 2I). Vegetative cells of strain TIO523 were from 33.5 to $55.7 \mu \mathrm{m}$ (mean $=42.9 \pm 5.1 \mu \mathrm{m}, n=53$ ) long and from 26.4 to $45.6 \mu \mathrm{m}$ (mean $=37.0 \pm 4.6 \mu \mathrm{m}, n=53$ ) wide.

Newly formed cysts were encountered in the bloom samples (Fig. 2A). They were spherical, with a diameter from 42.5 to $46.7 \mu \mathrm{m}$ (mean $=44.4 \pm 2.2 \mu \mathrm{m}, n=4$ ). These cysts were light brown and always had an accumulation body inside (Fig. 3A, B). The cysts had two thin walls each of them ornamented with numerous microreticulations on the surface (Fig. 3C-E). The equivalent of ASC was imprinted on the cyst wall comprising three rows of elongated vesicles (Fig. 3D, E).

The mature cysts from the sediments were dark brown with a diameter from 39.5 to $52.7 \mu$ m (mean $=45.8 \pm 3.1 \mu \mathrm{m}, n=26$ ) (Fig. 3F). The archeopyle was chasmic following the edge of the cingulum (Fig. 3G). The inner wall of the cysts was approximately $0.8 \mu \mathrm{m}$ thick (Fig. 3H).

\subsection{Molecular analysis}

Four isolates of $G$. catenatum from the bloom samples and five $G$. catenatum strains (Table 1) shared identical LSU rRNA gene sequences with those of other strains CCMP414 (DQ779990, Spain), GCCW991
(DQ779989, South Korea), GCCV-11 (JQ616825, Mexico), DC99A44 (AY036127, Singapore), GCCC21 (AY036072, Australia), and VGO743 (FN647677, Algeria). Nine isolates of $G$. catenatum from the bloom samples and five $G$. catenatum strains shared identical ITS-5.8S rRNA gene sequences with other strains GCCW991 (DQ779989, South Korea), CCMP414 (DQ779990, Spain), GCCV-11 (JQ616825, Mexico), CSIC744 (AM998536, Algeria), CS-397 (FJ823540, Japan), and they also had cytosine at the 5 th base of the 5.8S rRNA gene. No SNPs were observed in the ITS region and LSU rRNA gene of our strains.

\subsection{Cell dynamics of G. catenatum}

\subsubsection{Cell dynamics in the Taiwan Strait}

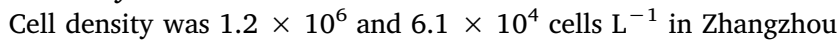
(stations ZP1, ZP2 in Fig. 1) and Quanzhou (station SS1 in Fig. 1) on June 9, 2017 and June 8, 2018, respectively, as determined by LM when the water temperature was around $26{ }^{\circ} \mathrm{C}$. Using qPCR, around three cells $\mathrm{L}^{-1}$ cells were detected at only one station (Q00) in November 2018 (Fig. 4A), and at only one station (X01) in July 2019 (Fig. 4C). Cells were detected at four stations (P05, P11, Q01-2 and Q05) in May 2019, with the maximum density $\left(\sim 75.8\right.$ cells $\left.\mathrm{L}^{-1}\right)$ at station P05 (Fig. 4B).

\subsubsection{Cell dynamics in Xiamen Bay}

Cells were only encountered once, with a cell density around 20 

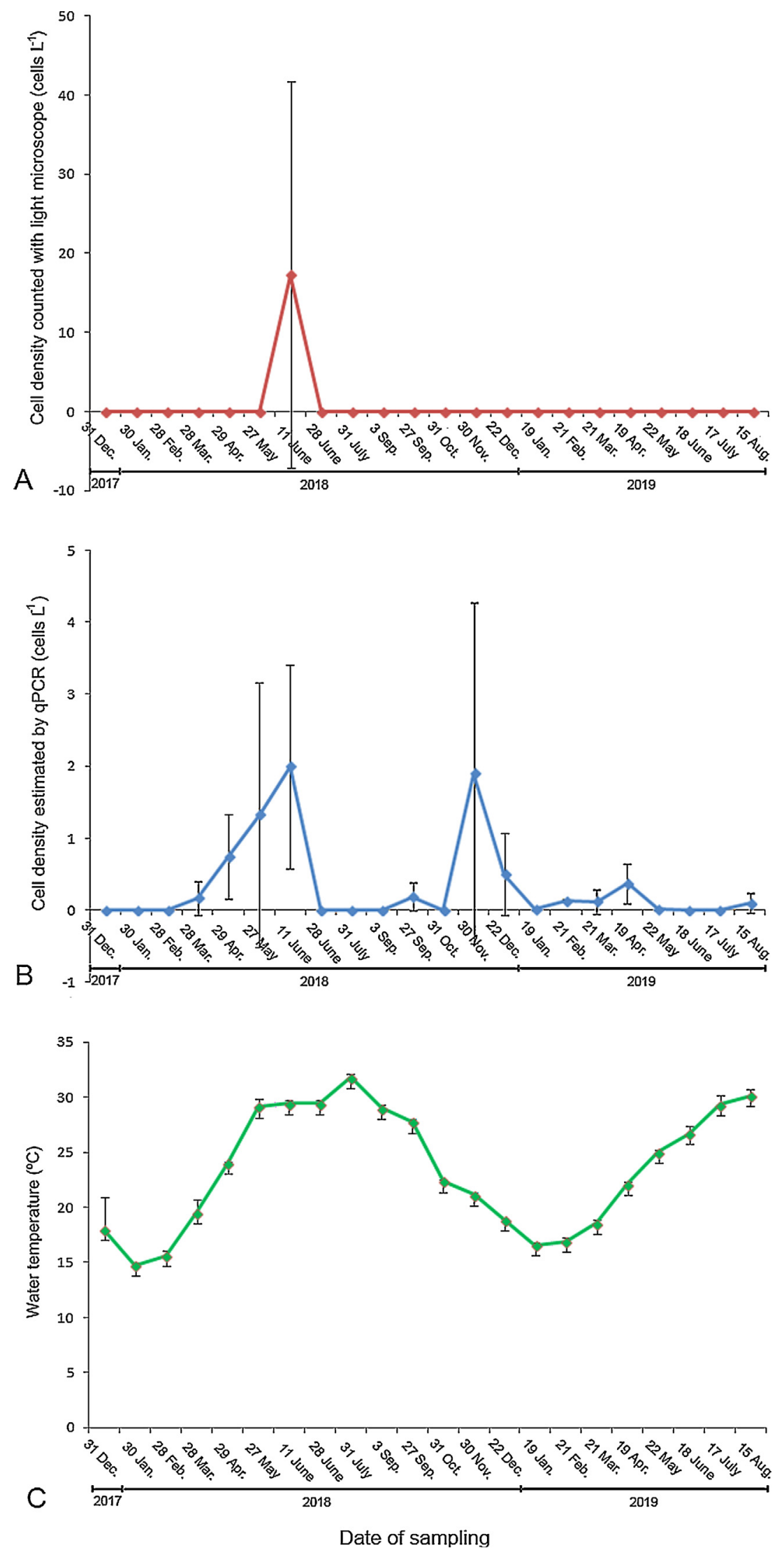

Fig. 5. Cell abundance of Gymnodinium catenatum in water samples in Xiamen Bay from December 2017 to August 2019. (A) Cell abundance examined by LM (B) Cell abundance examined by qPCR. (C) Water temperatures in Xiamen Bay from December 2017 to August 2019. 


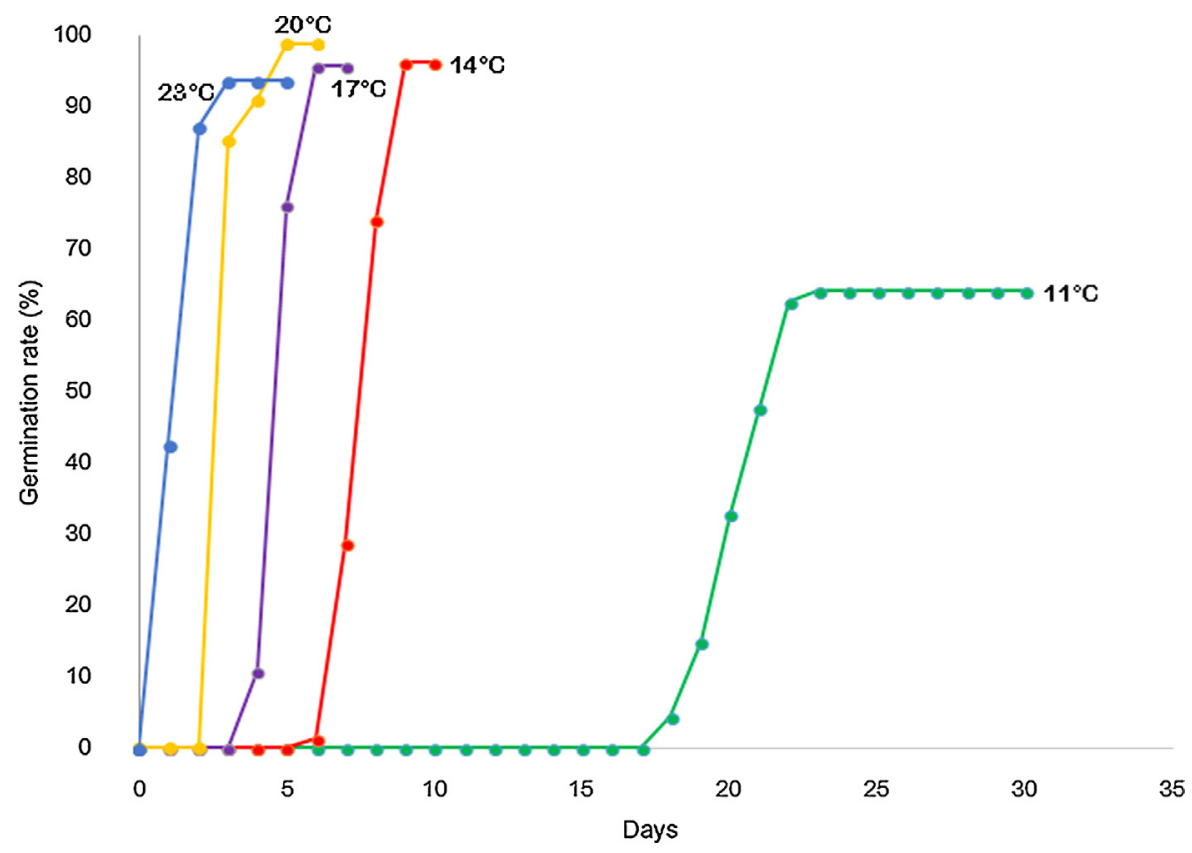

Fig. 6. Cumulative percentage germination over time of Gymnodinium catenatum cysts at a range of temperatures.

cells $\mathrm{L}^{-1}$ on June 11, 2018, as determined by LM (Fig. 5A). However, using qPCR, cells were detected in May, June, September, November, and December in 2018 and from February to April and August in 2019, although the cell density was lower than 2 cells $\mathrm{L}^{-1}$ (Fig. 5B).

\subsection{Germination of $G$. catenatum cysts}

The germination rate was only $64 \%$ at $11{ }^{\circ} \mathrm{C}$, but exceeded $93 \%$ from 14 to $23^{\circ} \mathrm{C}$ (Fig. 6). The time needed for germination was shorter as the temperature increased. Germination was not observed until 18 days at $11{ }^{\circ} \mathrm{C}$, but it took only six, four, three and one day at $14,17,20$, and $23{ }^{\circ} \mathrm{C}$, respectively. Moreover, germinated cells did not divide at $11{ }^{\circ} \mathrm{C}$. The germination rate decreased to only $73 \%$ at $23{ }^{\circ} \mathrm{C}$ after storage for two years at $4{ }^{\circ} \mathrm{C}$.

\subsection{Cyst abundance of $G$. catenatum}

\subsubsection{Cyst abundance in the Taiwan Strait}

Cysts were detected at 10 of the 16 stations in April 2016, but cyst density was generally low, ranging from 0.4 to 2.8 cysts $\mathrm{cm}^{-3}$ (Fig. 7A). However, cyst density reached a maximum of 40.8 cysts $\mathrm{cm}^{-3}$ from stations collected in March 2018 (Fig. 7B). Cysts were found in only two of 10 stations in November 2018, with a density ranging from 0.4 to 1.2 cysts $\mathrm{cm}^{-3}$ (Fig. 7C), in three of eight stations in May 2019, which ranged from 0.4 to 4.8 cysts $\mathrm{cm}^{-3}$ (Fig. 7D), and in six of eight stations in August 2019, with a range from 0.4 to $4.8 \mathrm{cysts}^{-3}$ (Fig. 7E). Only one cyst was found in samples from the 13 stations near Quanzhou that were collected on July 8, 2018, where a small bloom broke out on June 8, 2018.

\subsubsection{Cyst abundance in Xiamen Bay}

A preliminary survey around Xiamen Island on November 13, 2017 showed that cysts were present at 11 out of the 14 stations; with the largest densities in the Jiulong river estuary $\left(15.3\right.$ cysts $\left.\mathrm{cm}^{-3}\right)$ and Western Harbor (14.1 cysts $\mathrm{cm}^{-3}$ ) (Fig. 7F). Intensive sampling in these two areas in March 2018 showed that the cysts were present in all 11 stations, with a cyst density ranging from 1.2 to 84.4 cysts $\mathrm{cm}^{-3}$ (Fig. 7G). Empty cysts were found at some stations, accounting for $50 \%$ of all cysts at some stations. Cyst abundance rapidly decreased, with a maximum of 7.2 cysts $\mathrm{cm}^{-3}$ in May 2018 (Fig. 7H). Cyst abundance in
March 2019 was also low, with a maximum of 6.8 cysts $\mathrm{cm}^{-3}$ (Fig. 7I).

Cysts also had a vertical distribution and decreased with time. At station JL11, the maximum density of 689 cysts $\mathrm{cm}^{-3}$ was found at $18-20 \mathrm{~cm}$ in March 2018, but this decreased to 58 cysts $\mathrm{cm}^{-3}$ at 12-14 cm in May 2018 (Fig. 8A). At station 7-1, the maximum density of 32 cysts $\mathrm{cm}^{-3}$ was found at $12-14 \mathrm{~cm}$ in March 2018, which decreased to 19 cysts $\mathrm{cm}^{-3}$ at 4-6 $\mathrm{cm}$ in May 2018 (Fig. 8B).

\subsection{Growth experiment}

Strain TIO523 from the Taiwan Strait displayed growth at temperatures between 17 and $26^{\circ} \mathrm{C}$ (Fig. 9A). The highest division rate was $0.53 \pm 0.10$ divisions $\mathrm{d}^{-1}$ at $23^{\circ} \mathrm{C}$, which dropped slowly at higher and lower temperatures. Division rates were similar at temperatures of $20{ }^{\circ} \mathrm{C}$ and $26{ }^{\circ} \mathrm{C}$ (around 0.40 divisions $\mathrm{d}^{-1}$ ) and higher than those at $17{ }^{\circ} \mathrm{C}\left(0.34\right.$ divisions $\left.\mathrm{d}^{-1}\right)$.

Strain GCLY02 from the Yellow Sea displayed growth at temperatures between $14{ }^{\circ} \mathrm{C}$ and $26{ }^{\circ} \mathrm{C}$ (Fig. 9B). The highest division rate was $0.49 \pm 0.17$ divisions $\mathrm{d}^{-1}$ at $23{ }^{\circ} \mathrm{C}$, which then declined at higher and lower temperatures. Division rates were similar at temperatures of $14{ }^{\circ} \mathrm{C}$ and $26{ }^{\circ} \mathrm{C}$ (around 0.13 divisions $\mathrm{d}^{-1}$ ).

\subsection{Toxin profiles}

All three strains, as well as cysts, were able to produce PSTs (Fig. 10). $N$-sulfocarbamoyl toxins (C1/2, 53.0-143.5 $\mathrm{pg}^{\text {cell }}{ }^{-1}$ ) were dominant in all strains, followed by decarbamoyl gonyautoxins (dcGTX2/3, 26.7-52.1 pg cell ${ }^{-1}$ ), saxitoxin (STX, 0.3-14.8 $\mathrm{pg} \mathrm{cell}^{-1}$ ), and traces of GTX1/4 (0.7-2.3 pg cell $\left.{ }^{-1}\right)$, GTX2/3 $\left(0.2-0.4 \mathrm{pg} \mathrm{cell}^{-1}\right)$, $N$-sulfocarbamoyl B1 (= GTX5, 0.2-1.9 $\mathrm{pg} \mathrm{cell}^{-1}$ ) and dcSTX (0.6-1.4 pg cell $\left.{ }^{-1}\right)$. Cysts only produced B1 $\left(6.5 \mathrm{pg}^{\text {cell }}{ }^{-1}\right)$ and dcSTX $(0.6 \mathrm{pg}$ cell $^{-1}$ ). Seven different GC toxins were detected in both cells and cysts (Table 2), but the profiles varied among strains and cysts. While GC1 and GC3 were present in all samples all other GC toxins were only present in some of the samples. For example, GC3b was only detected in cysts, but not in any of the isolated strains. In contrast, GC1a, GC2a, and GC6 were only detected in strains, but not in cysts (Table 2). 
Gymnodinium catenatum cysts (cysts $\mathrm{cm}^{-3}$ ) Apr. 2016

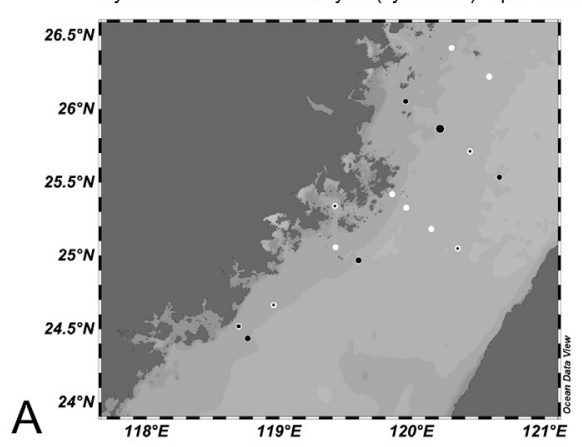

Gymnodinium catenatum cysts (cysts $\mathrm{cm}^{-3}$ ) Mar. 2018

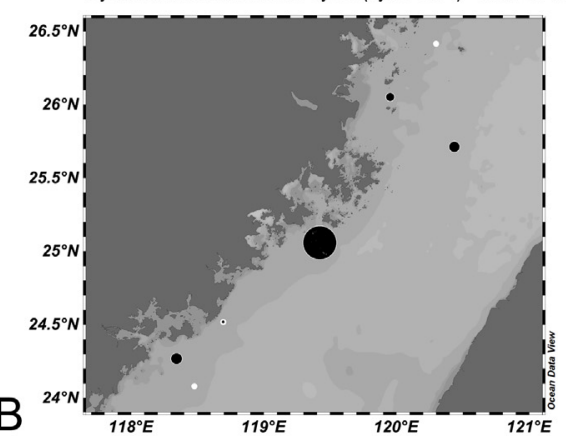

Gymnodinium catenatum cysts (cysts $\mathrm{cm}^{-3}$ ) Nov. 2018

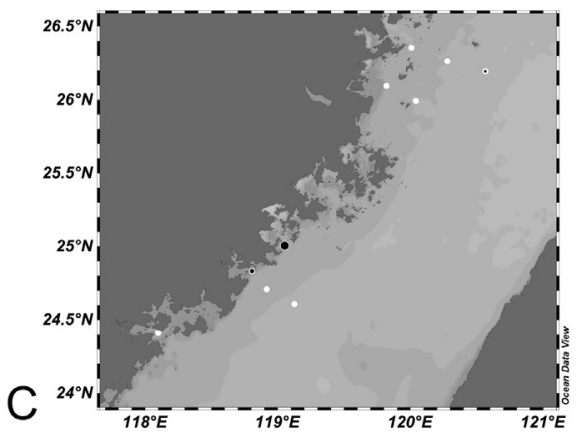

Gymnodinium catenatum cysts (cysts $\mathrm{cm}^{-3}$ ) May 2019

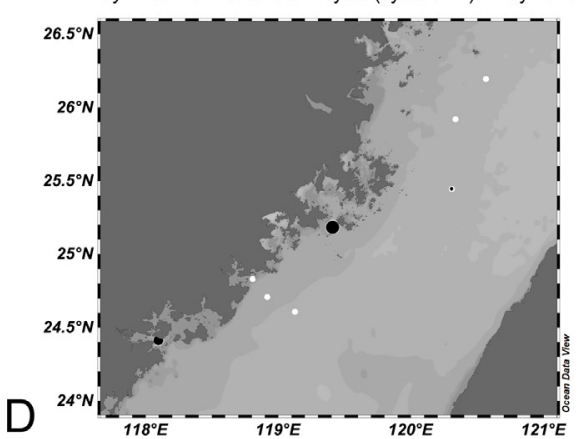

Gymnodinium catenatum cysts (cysts $\mathrm{cm}^{-3}$ ) July 2019

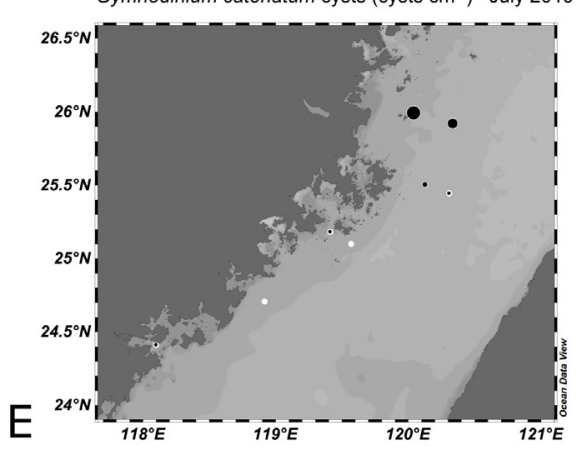

Gymnodinium catenatum cysts (cysts $\mathrm{cm}^{-3}$ ) Nov. 2017

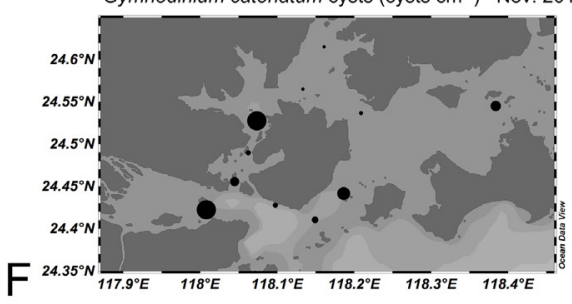

Gymnodinium catenatum cysts (cysts $\mathrm{cm}^{-3}$ ) Mar. 2018

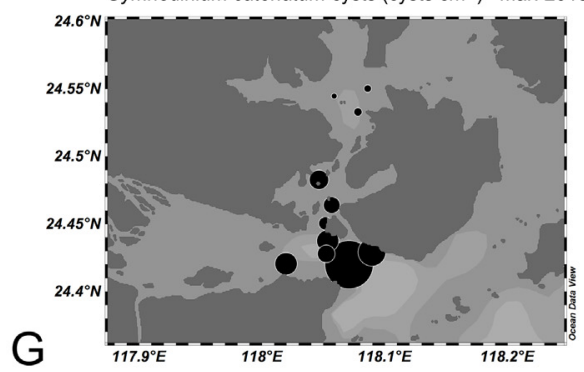

Gymnodinium catenatum cysts (cysts $\mathrm{cm}^{-3}$ ) May 2018

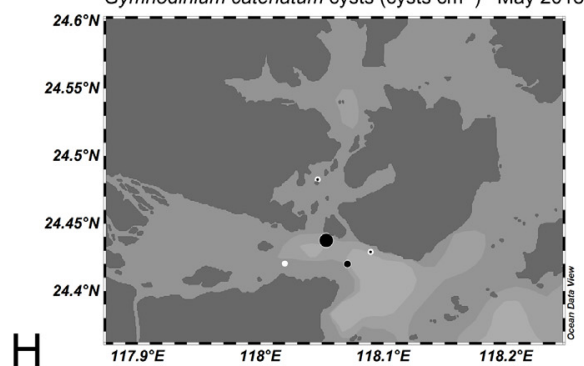

Gymnodinium catenatum cysts (cysts $\mathrm{cm}^{-3}$ ) Mar. 2019

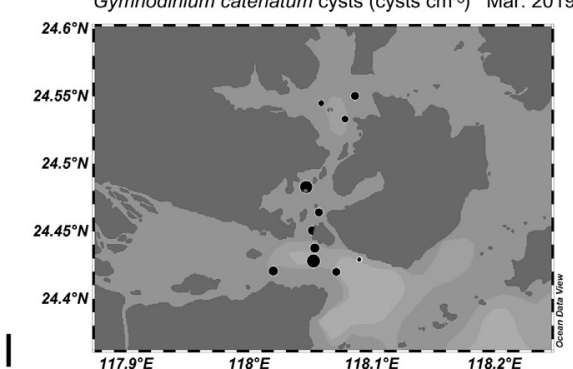

scales

cysts $\mathrm{cm}^{-3}$

10

20

80

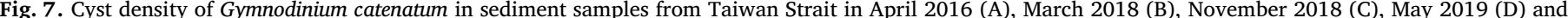
July 2019 (E), and in Xiamen Bay in November 2017 (F), March 2018 (G), May 2018 (H) and March 2019 (I).

\section{Discussion}

4.1. Morphological and molecular characterization of $G$. catenatum in the Taiwan Strait

There is morphological and molecular evidence that $G$. catenatum is responsible for the blooms in the Taiwan Strait in June of 2017 and 2018. A morphologically similar species, G. impudicum, was also responsible in the bloom sample in June 2018, but its density was low (Gu personal observation). Gymnodinium impudicum can be separated from G. catenatum due to its smaller size (average lengths 17 vs. $34 \mu \mathrm{m}$ ) and its formation of shorter chains (maximum 16 vs. 64 cells) (Fraga et al., 

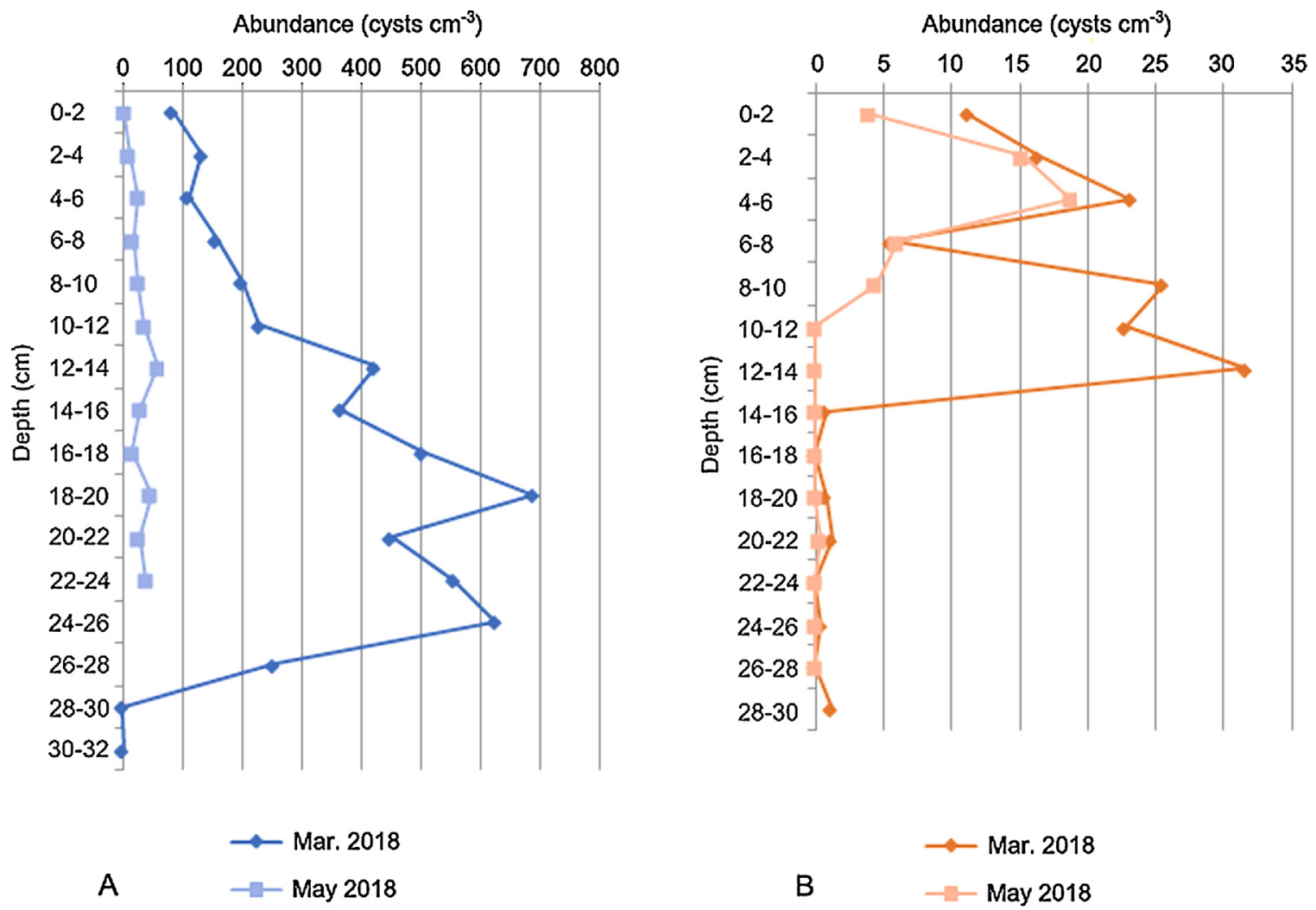

Fig. 8. Vertical distribution of Gymnodinium catenatum cysts in sediment cores of stations JL11 (A) and 7-1 (B) from Xiamen Bay in March 2018 and May 2018.

1995).

Gymnodinium catenatum cells collected on June 9, 2017 ranged from 30 to $52 \mu \mathrm{m}$ in length, larger than typical cells (23 to $41 \mu \mathrm{m}$ in length) as reported previously (Rees and Hallegraeff, 1991). Cysts were also present in the water samples suggesting that some of those large cells were probably planozygotes. The cyst sizes from the Taiwan Strait were significantly smaller $(45.8 \pm 3.1 \mu \mathrm{m})$ than those from the Yellow Sea $(49.7 \pm 4.0 \mu \mathrm{m}, n=9)(P<0.01$, Gu et al., 2013). A cyst size difference was also reported in Australian specimens and may be a genetically determined, population-specific characteristic (Bolch and Reynolds, 2002). In contrast, cysts of Gymnodinium nolleri and Gymnodinium microreticulatum were less than $38 \mu \mathrm{m}$ and $28 \mu \mathrm{m}$, respectively (Bolch et al., 1999; Ellegaard and Moestrup, 1999).

New morphological details were obtained for G. catenatum, especially the details of the ASC. An ASC consisting of three elongated vesicles has been reported in Levanderina fissa (Moestrup et al., 2014), Barrufeta resplendens (Gu et al., 2015), Gymnodinium dorsalisulcum, and Gymnodinium impudicum (Luo et al., 2018), but this is the first time three elongated vesicles have been reported in $G$. catenatum, especially in newly formed cysts (Fig. 3D). Numerous small knobs were present in the middle of the ASC in G. catenatum, as also reported in Levanderina fissa (Moestrup et al., 2014) and Barrufeta resplendens (Gu et al., 2015), but they were located in the outer row of vesicles in $G$. dorsalisulcum and G. impudicum (Luo et al., 2018). We also identified the small knobs that emerged from the round pores for the first time; however, the details of the ASC in G. fuscum, the type species of Gymnodinium, is not yet available (Romeikat et al., 2020). Molecular phylogeny based on concatenated rRNA gene sequences revealed that $G$. catenatum is distant from $G$. fuscum but is grouped together with G. nolleri, G. microreticulatum, G. trapeziforme and $G$. inusitatum; all of them have a microreticulate cyst (Gu et al., 2013; Wang et al., 2017; Romeikat et al., 2020). This may therefore warrant a new genus.

Gymnodinium catenatum strains from the Taiwan Strait had cytosine (C-gene) at the 5th base of the 5.8S rRNA gene, as also reported in strains from Spain, Portugal, Uruguay, Singapore, South Korea, Hong Kong, Japan (Bolch and De Salas, 2007), the Yellow Sea, China (Gu et al., 2013), Mexico, and Algeria, suggesting that this ribotype represents a global population (Table 3). In contrast, G. catenatum strains from Australia, New Zealand, and Japan had a thymidine (Tgene) at the 5th base of the 5.8S rRNA gene (Bolch and De Salas, 2007). An LSU RNA gene sequence comparison also revealed that our strains of G. catenatum shared identical sequences with those obtained elsewhere. The only exceptions were one Spanish strain, which differed in five positions (Hansen et al., 2000) and several strains from Bahía Concepción, Mexico, which had a cytosine instead of guanine at position 453 (Band-Schmidt et al., 2008). No SNP was observed in the ITS region of our strains, unlike some Portuguese strains, which have two SNP at positions 57 and 117 of the ITS1 region (Silva et al., 2015).

\subsection{The G. catenatum ecotype in the Taiwan Strait}

Recurrent G. catenatum blooms occur in the Taiwan Strait in early summer when water temperatures are around $26{ }^{\circ} \mathrm{C}$, suggesting that this population belongs to the warm water ecotype, as also reported in Manila Bay in The Philippines, Singapore, Sabah in Malaysia, Thailand, and Acapulco Bay in Mexico (Corrales et al., 1996; Holmes et al., 2002; Lirdwitayaprasit et al., 2008; Adam et al., 2011; del Castillo et al., 2020). In contrast, blooms have been reported in the Gulf of California, southern Tasmanian estuaries, and Rías Baixas of Galicia, Spain where water temperatures are between $12{ }^{\circ} \mathrm{C}$ and $17{ }^{\circ} \mathrm{C}$, suggesting that these are populations of cold water ecotypes (Graham, 1943; MoreyGaines, 1982; Hallegraeff et al., 1988; Figueroa et al., 2008). A moderate ecotype might exit based on blooms recorded in Bahía Concepción, Mexico (18.0-25.0 ${ }^{\circ} \mathrm{C}$ ) (Gárate-Lizárraga et al., 2004), Mazatlán, Sinaloa in Mexico $\left(22^{\circ} \mathrm{C}\right.$ ) (Morey-Gaines, 1982), and in the Yellow Sea, China $\left(23.0^{\circ} \mathrm{C}\right.$ ) (Jiao et al., 2010).

The growth experiments also suggest that there were different ecotypes within $G$. catenatum. Our strains grew best at $23{ }^{\circ} \mathrm{C}$, but the 

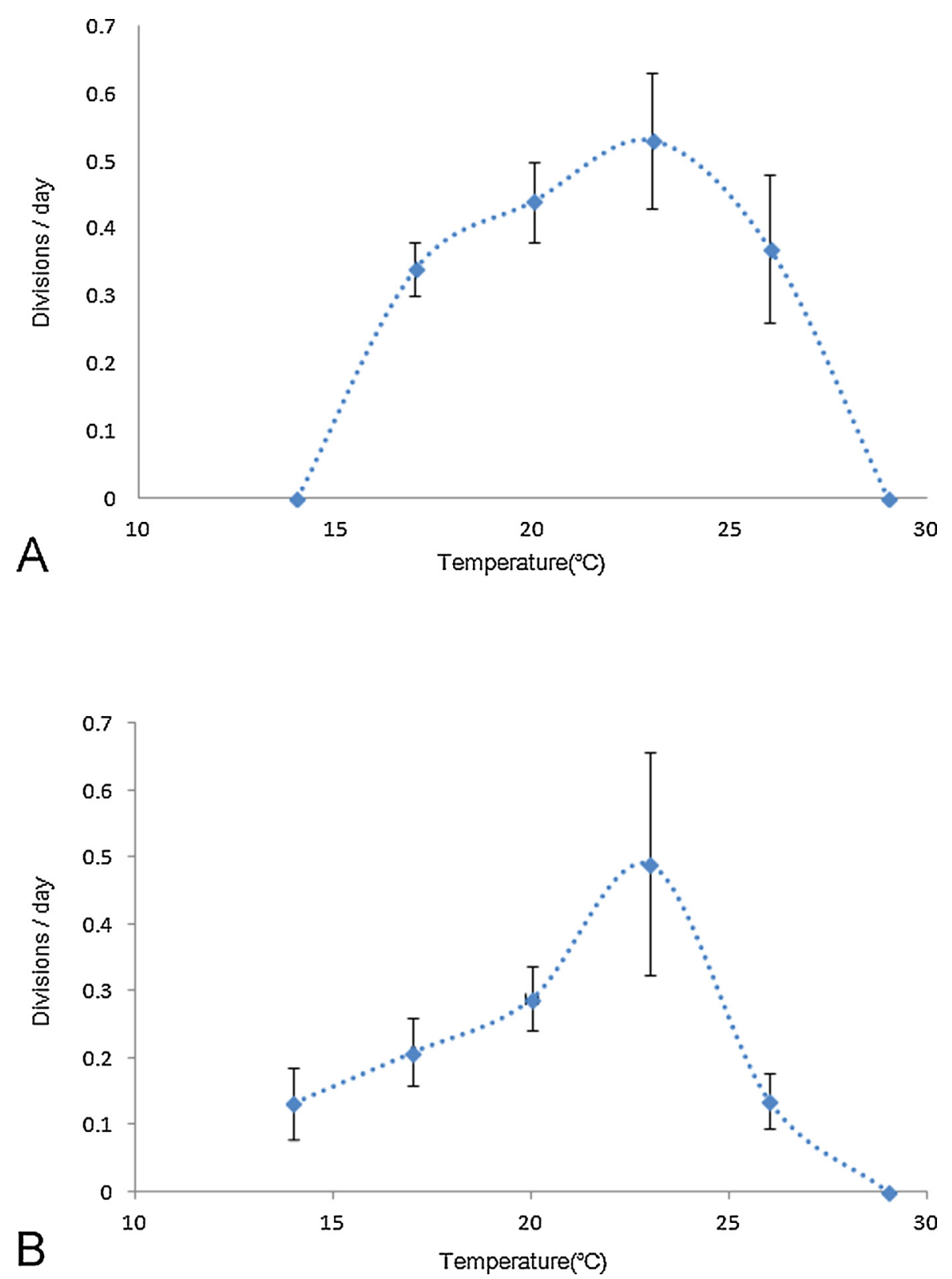

Fig. 9. Growth responses of Gymnodinium catenatum under various temperatures. (A) strain TIO523 from Taiwan Strait; (B) strain GCLY02 from Yellow Sea.

maximum growth rate $\left(0.31 /\right.$ day) was obtained at $25{ }^{\circ} \mathrm{C}$ and $30{ }^{\circ} \mathrm{C}$ in a strain isolated from Hiroshima Bay, Japan (Yamamoto et al., 2002), and a strain from Hong Kong that grew best at $25^{\circ} \mathrm{C}$ (Zhang, 2009). Several strains from the Pacific coast of Mexico and northwest Spain showed maximum growth at $24{ }^{\circ} \mathrm{C}$ or even $30{ }^{\circ} \mathrm{C}$ (Bravo and Anderson, 1994; Band-Schidmt et al., 2014). In contrast, the vegetative growth of strains from Tasmania, Australia was optimal at temperatures from 14.5 to $20{ }^{\circ} \mathrm{C}$ (Blackburn et al., 1989), which was consistent with the bloom temperatures (Hallegraeff et al., 1988). However, strains from the same locality might display different physiological responses, e.g., two strains from Bahía Concepción grew from 15 to $29^{\circ} \mathrm{C}$ with highest growth rates from 21 to $29{ }^{\circ} \mathrm{C}$ (Band-Schmidt et al., 2004) and 21-30 ${ }^{\circ} \mathrm{C}$ (BandSchmidt et al., 2010), implying that different ecotypes might occur in sympatry. Although both of our strains grew best at $23^{\circ} \mathrm{C}$, GCLY02 from the Yellow Sea displayed growth at $14{ }^{\circ} \mathrm{C}$ whereas TIO523 from the Taiwan Strait did not, suggesting that they were physiologically differentiated.

\subsection{Coupling of cyst and cell dynamics}

4.3.1. G. catenatum cyst germination

Cysts must spend a period of dormancy before germination. This dormancy can last from six days to two weeks for Australian (Blackburn et al., 1989) and Spanish G. catenatum cysts (Figueroa et al., 2006; Bravo et al., 2010; Figueroa et al., 2010). Unfortunately, the dormancy period of cysts in Taiwan Strait is unknown because we failed to generate cysts in culture. Cyst germination was observed at $11{ }^{\circ} \mathrm{C}$ after 17 days of incubation in cysts from the Taiwan Strait, however Australian cyst germination occurred at $4{ }^{\circ} \mathrm{C}$ (Blackburn et al., 1989), indicating that they belong to warm and cold ecotypes, respectively. Cysts have been reported to remain viable in a darkened refrigerator for one year (Blackburn et al., 1989), but in this study we found that they remained alive for at least two years, suggesting that they have the potential to consistently provide seedlings.

4.3.2. G. catenatum cyst dynamics

Gymnodinium catenatum cysts are rare and often not detected 


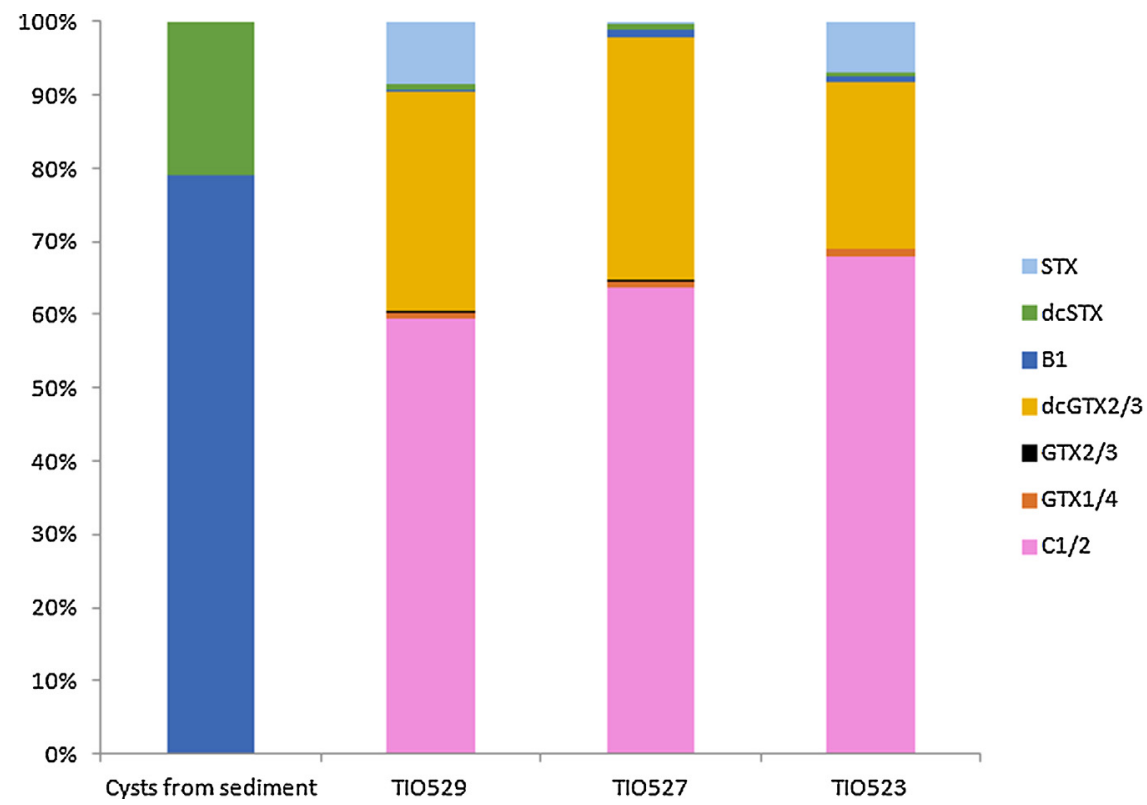

Fig. 10. Histograms showing the PSTs toxin composition of Gymnodinium catenatum strains established by germinating cysts and cysts from the sediment.

Table 2.

PST profiles of Chinese Gymnodinium catenatum strains and cysts (pg cell ${ }^{-1}$; +: present; nd: not detected).

\begin{tabular}{|c|c|c|c|c|c|c|c|c|c|c|c|c|c|c|}
\hline & $\mathrm{C} 1 / 2$ & GTX1/4 & GTX2/3 & dcGTX $2 / 3$ & B1 & dcSTX & STX & GC1 & GC2 & GC3 & GC1a & GC2a & GC3b & GC6 \\
\hline Cysts & nd & nd & nd & nd & 6.5 & 1.7 & nd & + & + & + & nd & nd & + & nd \\
\hline TIO529 & 53.0 & 0.7 & 0.2 & 26.7 & 0.2 & 0.6 & 7.6 & + & nd & + & nd & nd & nd & + \\
\hline TIO527 & 99.8 & 1.3 & 0.3 & 52.1 & 1.6 & 1.4 & 0.3 & + & + & + & nd & nd & nd & nd \\
\hline TIO523 & 143.5 & 2.3 & 0.4 & 48.0 & 1.9 & 0.8 & 14.8 & + & nd & + & + & + & nd & + \\
\hline
\end{tabular}

(Godhe et al., 2001; Pospelova et al., 2002; Joyce, 2004; Zonneveld et al., 2009; Satta et al., 2010;), typically accounting for less than $3 \%$ of the total cyst assemblage (Matsuoka and Fukuyo, 1994; Godhe et al., 2000; Pospelova and Kim, 2010). Gymnodinium catenatum cysts were also rare in the Taiwan Strait before the bloom (Fig. 7A); however, cyst density increased rapidly after the bloom, as reported here (Fig. 7B), and in Spain (Bravo et al., 2010). A high cyst density was also reported in Bahía Concepción, Mexico and southern Tasmania where G. catenatum blooms are common (Bolch and Hallegraeff, 1990; Morquecho and Lechuga-Devéze, 2004). It is therefore reasonable to assume that encystment might play an important role in the decline of G. catenatum blooms.

The absence of cysts in sediments from locations where blooms occurred in June 2018 suggested that local cyst production might not necessarily be reflected in the sediments. The cyst concentration was quite uneven in the Taiwan Strait and Xiamen Bay, with high cyst densities observed at only a few stations (Figs. 7B and 8B), supporting the idea that sedimentation plays an important role in cyst distribution (Dale, 1976). The presence of cysts in sediment as deep as $32 \mathrm{~cm}$ in Xiamen Bay was surprising as they were not detected during previous surveys (Gu personal observation). The vertical distribution of cysts might be attributed to disturbances by regular dredging in Xiamen

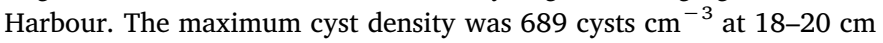
in Xiamen Bay, compared to 1900 cysts $\mathrm{cm}^{3}$ after the bloom on the Galician coast (Bravo et al., 2010). However, there was a considerable decrease in cyst density in the Taiwan Strait as well as in Xiamen Bay, as also reported in the Rias Baixas of Galicia, Spain (Bravo et al., 2010). Therefore, the role of the cyst bank in bloom initiation cannot be overestimated.

\subsubsection{Cell dynamics}

Gymnodinium catenatum cells are present in the Taiwan Strait and
Xiamen Bay throughout the year, although the cell density is low. These cells may persist in the water column or be supplemented from cysts because continuous germination is possible. Persistent cells were also reported in the Galician coast (Bravo et al., 2010) and southern Tasmanian waters (Hallegraeff et al., 1995) where recurrent blooms have occurred, suggesting that these cells have the potential to initiate a bloom. The two blooms were observed very close to the coast (stations ZP1, ZP2 and SS1 in Fig. 1) in 2017 and 2018, raising the question of whether they were local or transported from offshore. The relatively high concentration of cells at station P05 in May, 2019 (Fig. 4B) suggested that the advection of cells from offshore to the coast is possible, as also reported in the Galician coast (Bravo et al., 2010). It is interesting to note that the two blooms in the Taiwan Strait were consistent with the occurrence of the $2017 / 2018$ La Niña (Zhang et al., 2019). The cold La Niña events would cause a partial stratification of the water column with a shallow nutricline favoring $G$. catenatum, which could migrate vertically (Fraga and Bakun, 1993).

\subsection{Toxin profiles}

At least 36 people from Zhangzhou were intoxicated after consuming mussels on June 8, 2017 (Chen, 2018). The occurrence of a G. catenatum bloom in this area (stations ZP1, ZP2 in Fig. 1) on June 9, 2017 and the detection of PSTs in the strains confirmed that this species was responsible for the intoxication event. The toxin profiles are useful markers enabling the differentiation of populations from different regions (Negri et al., 2007). Strains from the Taiwan Strait produce predominately $\mathrm{C} 1+2$ and dcGTX $2+3$ without $\mathrm{C} 3+4$, and therefore can be separated from the Hong Kong and Yellow Sea strains, which produce abundant C3/C4 (Negri et al., 2001; Gu et al., 2013). The Taiwan Strait strains also differ from those in Singapore which do not produce C toxins and dcGTX2/3 (Holmes et al., 2002). The Taiwan Strait strains 


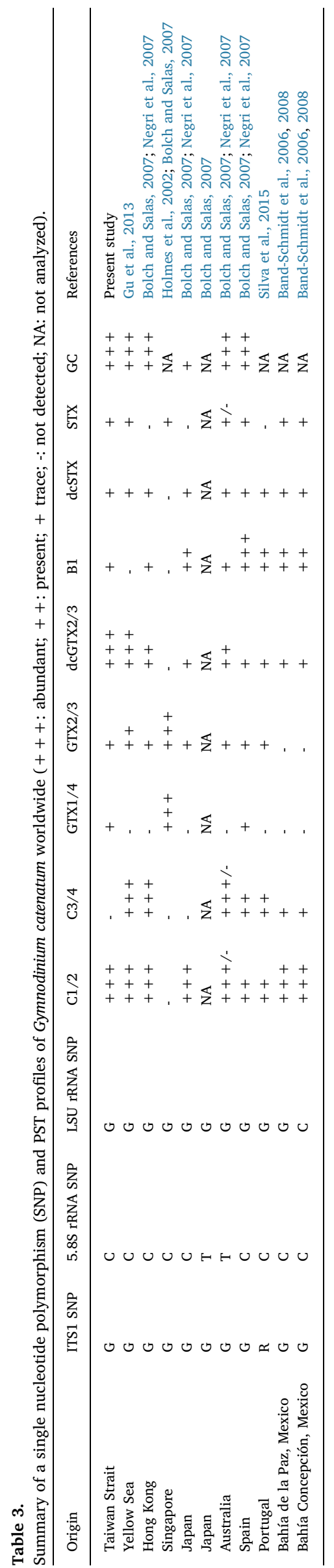

were similar to Japanese strains in that neither of them produce $\mathrm{C} 3+4$; however, no GC toxins were reported for Japanese strains (Negri et al., 2007; Oh et al., 2010). The lack of detection of GC toxins in the Japanese $G$. catenatum strains may very well be a methodological issue and does not necessarily reflect the absence of GC toxins in these strains. In 2007, when Negri et al. (2007) published their results, only GC1, GC2, and GC3 were known and accordingly only these three variants were tested for and were found to not be present in the Japanese strains. Oh et al. (2010) did not test for the presence of GC toxins at all. For this reason very little information on the production of GC toxins by Japanese strains of $G$. catenatum is available. Given that GC1 and GC3 were present in all G. catenatum samples from the Taiwan Strait including strains and cysts, but were absent in the Japanese strains analyzed by Negri et al. (2007), the GC toxin profiles clearly differ between $G$. catenatum populations in Japanese and Chinese coastal waters. In addition, the production of GTX1/4 and STX also separate our strains from those from Australia, South Korea, Mexico, Spain, Portugal and Uruguay, and Malaysia (Hallegraeff et al., 2012). Our strains were unique in the PST profiles compared to strains from elsewhere (Table 3), suggesting that they represented a separate population.

The PST profiles of $G$. catenatum cysts is reported here for the first time, rejecting the idea that bacterial community is necessary for PST production in G. catenatum (Albinsson et al., 2014). Only B1, dcSTX and four GC toxins were detected compared to 17 toxins identified in the cells. In contrast, Alexandrium tamarense cysts produce the same ten toxic components as vegetative cells, which only differ in their relative abundance (Oshima et al., 1992). The toxicity of Alexandrium cysts have been reported to be ten and six-fold higher than that of cells (Dale et al., 1978; Oshima et al., 1992), but a similar toxicity of cysts and cells has also been reported (Oshima et al., 1982; White and Lewis, 1982). Alexandrium tamarense is known to comprise several different species and their toxicity can vary (John et al., 2014). Alexandrium tamarense is now considered to be an entirely nontoxic species, and therefore the previous surveys definitively refer to different species according to the current taxonomic nomenclature. Gymnodinium catenatum cysts are able to produce GC toxins, but quantification is not possible due to a lack of standards. During routine shellfish monitoring GC toxins are often neglected, which might underestimate the potential risk of $G$. catenatum blooms.

\section{Conclusion}

The findings of complex GC toxin profiles in G. catenatum strains from Taiwan Strait highlight the importance of toxicity testing of GC toxins and their survey in monitoring programs in this region. Cyst survey during routine monitoring will also help to predict potential future blooms.

\section{Declaration of Competing Interest}

The authors declare that they have no known competing financial interests or personal relationships that could have appeared to influence the work reported in this paper.

\section{Acknowledgments}

This project was supported by the Natural Science Foundation of Fujian, China (2019J05150), Scientific Research Foundation of Third Institute of Oceanography, MNR (2019017), the National Natural Science Foundation of China (41676117), the Natural Science Foundation of Fujian, China (2017J05051), the National Key Research and Development Program of China (2016YFE0202100) and by the Helmholtz-Gemeinschaft Deutscher Forschungszentren through the research program "Polar regions And Coasts in the changing Earth 
System" (PACES II) of the Alfred-Wegener-Institut, Helmholtz Zentrum für Polar- und Meeresforschung. Data and samples were collected onboard of R/V "Beidou" implementing the open research cruise NORC2019-01 supported by NSFC Shiptime Sharing Project (41849901).

CG

\section{Supplementary materials}

Supplementary material associated with this article can be found, in the online version, at doi:10.1016/j.hal.2020.101868.

\section{References}

Adachi, M., Sako, Y., Ishida, Y., 1996. Analysis of Alexandrium (Dinophyceae) species using sequences of the $5.8 \mathrm{~S}$ ribosomal DNA and internal transcribed spacer regions. J. Phycol. 32 (3), 424-432.

Adam, A., Mohammad-Noor, N., Anton, A., Saleh, E., Saad, S., Muhd Shaleh, S.R., 2011 Temporal and spatial distribution of harmful algal bloom (HAB) species in coastal waters of Kota Kinabalu, Sabah, Malaysia. Harmful Algae 10 (5), 495-502.

Albinsson, M.E., Negri, A.P., Blackburn, S.I., Bolch, C.J.S., 2014. Bacterial community affects toxin production by Gymnodinium catenatum. PloS One 9 (8), e104623.

Amorim, A., Dale, B., 2006. Historical cyst record as evidence for the recent introduction of the dinoflagellate Gymnodinium catenatum in the north-eastern Atlantic. Afr. J. Mar. Sci. 28 (2), 193-197.

Anderson, D., Jacobson, D.M., Bravo, I., Wrenn, J., 1988. The unique microreticulate cysts of the naked dinoflagellate Gymnodinium catenatum Graham. J. Phycol. 24, 255-262.

Andersen, P., Throndsen, J., 2004. Estimating cell numbers. In: Hallegraeff, G.M., Anderson, D.M., Cembella, A.D. (Eds.), Manual on Harmful Marine Microalgae. Monographs on Oceanographic Methodology 11. UNESCO Publishing, Paris, pp. 99-130.

Attaran-Fariman, G., De Salas, M.F., Negri, A.P., Bolch, C.J.S, 2007. Morphology and phylogeny of Gymnodinium trapeziforme sp. nov. (Dinophyceae): a new dinoflagellate from the southeast coast of Iran that forms microreticulate resting cysts. Phycologia 46 (6), 644-656.

Band-Schmidt, CJ, Bustillos-Guzmán, JJ, Hernández-Sandoval, FE, Núñez-Vázquez, EJ, López-Cortés, DJ., 2014. Effect of temperature on growth and paralytic toxin profiles in isolates of Gymnodinium catenatum (Dinophyceae) from the Pacific coast of Mexico. Toxicon 90, 199-212.

Band-Schmidt, C.J., Bustillos-Guzmán, J., Morquecho, L., Gárate-Lizárraga, I., AlonsoRodríguez, R., Reyes-Salinas, A., Erler, K., Luckas, B., 2006. Variations of PSP toxin profiles during different growth phases in Gymnodinium catenatum (Dinophyceae) strains isolated from three locations in the Gulf of California. Mexico. J. Phycol. 42, 757-768.

Band-Schmidt, C.J., Bustillos-Guzmán, J.J., López-Cortés, D.J., Gárate-Lizárraga, I., Núñez-Vázquez, E.J., Hernández-Sandoval, F.E., 2010. Ecological and physiological studies of Gymnodinium catenatum in the Mexican Pacific: a review. Mar. Drugs 8 (6), 1935-1961.

Band-Schmidt, C.J., Morquecho, L., Lechuga-Devéze, C.H., Anderson, D.M., 2004. Effects of growth medium, temperature, salinity and seawater source on the growth of Gymnodinium catenatum (Dinophyceae) from Bahía Concepción, Gulf of California, Mexico. J. Plankton Res. 26 (12), 1459-1470.

Band-Schmidt, C.J., Rojas-Posadas, D.I., Morquecho, L., Hernández-Saavedra, N.Y., 2008. Heterogeneity of LSU rDNA sequences and morphology of Gymnodinium catenatum dinoflagellate strains in Bahía Concepción, Gulf of California, Mexico. J. Plankton Res. 30 (7), 755-763.

Blackburn, S.I., Hallegraeff, G.M., Bolch, C.J.S., 1989. Vegetative reproduction and sexual life cycle of the toxic dinoflagellate Gymnodinium catenatum from Tasmania, Australia. J. Phycol. 25 (3), 577-590.

Blackburn, S.I., Bolch, C.J.S., Haskard, K.A., Hallegraeff, G.M., 2001. Reproductive compatibility among four global populations of the toxic dinoflagellate Gymnodinium catenatum (Dinophyceae). Phycologia 40 (1), 78-87.

Bolch, C.J.S., 1997. The use of sodium polytungstate for the separation and concentration of living dinoflagellate cysts from marine sediments. Phycologia 36 (6), 472-478.

Bolch, C.J.S., de Salas, M.F., 2007. A review of the molecular evidence for ballast water introduction of the toxic dinoflagellates Gymnodinium catenatum and the Alexandrium "tamarensis complex" to Australasia. Harmful Algae 6 (4), 465-485.

Bolch, C.J.S., Hallegraeff, G.M., 1990. Dinoflagellate cysts in recent marine sediments from Tasmania, Australia. Bot. Mar. 33 (2), 173-192.

Bolch, C.J.S., Negri, A.P., Hallegraeff, G.M., 1999. Gymnodinium microreticulatum sp. nov. (Dinophyceae): a naked, microreticulate cyst-producing dinoflagellate, distinct from Gymnodinium catenatum and Gymnodinium nolleri. Phycologia 38 (4), 301-313.

Bolch, C.J.S., Reynolds, M.J., 2002. Species resolution and global distribution of microreticulate dinoflagellate cysts. J. Plankton Res. 24 (6), 565-578.

Bravo, I., Anderson, D.M., 1994. The effects of temperature, growth medium and darkness on excystment and growth of the toxic dinoflagellate Gymnodinium catenatum from northwest Spain. J. Plank. Res 16, 513-525.

Bravo, I., Fraga, S., Isabel Figueroa, R.I., Pazos, Y., Massanet, A., Ramilo, I., 2010. Bloom dynamics and life cycle strategies of two toxic dinoflagellates in a coastal upwelling system (NW Iberian Peninsula). Deep-Sea Res. Pt II 57 (3-4), 222-234.
Bravo, I., Ramilo, I., 1999. Distribution of microreticulate cysts from the Galician and Portuguese coast. Sci. Mar. 63 (1), 45-50.

Bustillos-Guzmán, J.J., Band-Schmidt, C.J., Durán-Riveroll, L.M., Hernández-Sandoval, F.E., López-Cortés, D.J., Nuñez-Vazquez, E.J., Cembella, A., Krock, B., 2015. Paralytic toxin profile of the marine dinoflagellate Gymnodinium catenatum Graham from the Mexican Pacific as revealed by LC-MS/MS. Food Addit. Contam. A 32 (3), 381-394.

Chen, H., 2018. Emergency treatment and reflection of red tide event of Gymnodinium catenatum in Fujian sea area in 2017. J. Fisheries Res 40 (4), 308-314.

Corrales, R., Gonzalez, C., Roman, R., 1996. Gymnodinium catenatum Bloom: First Record for Manila Bay, Philippines. Phycotoxins@ biome. bio. dfo. ca 15.

Dale, B., 1976. Cyst formation, sedimentation, and preservation: factors affecting dinoflagellate assemblages in recent sediments from Trondheimsfjord, Norway. Rev. Palaeobot. Palynol. 22 (1), 39-60.

Dale, B., Yentsch, C.M., Hurst, J.W., 1978. Toxicity in resting cysts of the red-tide dinoflagellate Gonyaulax excavata from deeper water coastal sediments. Science 201 (4362), 1223-1225.

Daugbjerg, N., Hansen, G., Larsen, J., Moestrup, $\varnothing, 2000$. Phylogeny of some of the major genera of dinoflagellates based on ultrastructure and partial LSU rDNA sequence data, including the erection of three new genera of unarmoured dinoflagellates. Phycologia 39 (4), 302-317.

del Castillo, M.E.M., Zamudio-Reséndiz, M.E., Castillo-Rivera, M.A., Gutiérrez-Mendieta, F.J., Varona-Cordero, F., Hernández-Cárdenas, G., 2020. Co-ocurrence of two toxic dinoflagellates in Acapulco Bay, Gro., Mexico: An opportunity to quantify their biology and ecology. Acta Bot. Mex. 127, e1559.

Durán-Riveroll, LM, Krock, B., Cembella, A., Peralta-Cruz, J., José, J.Bustillos-Guzmán, Band-Schmidt, C.J., 2017. Characterization of benzoyl saxitoxin analogs from the toxigenic marine dinoflagellate Gymnodinium catenatum by hydrophilic interaction liquid Ionchromatography-tandem mass spectrometry. Nat. Prod. Chem. Res. 5, 275.

Ellegaard, M., Moestrup, $\varnothing, 1999$. Fine structure of the flagellar apparatus and morphological details of Gymnodinium nolleri sp. nov. (Dinophyceae), an unarmored dinoflagellate producing a microreticulate cyst. Phycologia 38 (4), 289-300.

Figueroa, R.I., Bravo, I., Garces, E., Ramilo, I., 2006. Nuclear features and effect of nutrients on Gymnodinium catenatum (Dinophyceae) sexual stages. J. Phycol 42 (1), $67-77$.

Figueroa, R.I., Bravo, I., Ramilo, I., Pazos, Y., Moroño, A., 2008. New life-cycle stages of Gymnodinium catenatum (Dinophyceae): laboratory and field observations. Aquat. Microb. Ecol 52, 13-23.

Figueroa, R.I., Rengefors, K., Bravo, I., Bensch, S., 2010. From homothally to heterothally: Mating preferences and genetic variation within clones of the dinoflagellate Gymnodinium catenatum. Deep-Sea Res. Pt II 57 (3-4), 190-198.

Flores-Trujillo, J.G., Helenes, J., Herguera, J.C., Orellana-Cepeda, E., 2009. Palynological record (1483-1994) of Gymnodinium catenatum in Pescadero Basin, southern Gulf of California, Mexico. Mar. Micropaleontol. 73 (1-2), 80-89.

Fraga, S., Bakun, A., 1993. Global climate change and harmful algal blooms: the example of Gymnodinium catenatum on the Galician coast. In: Smayda, T.J., Shimizu, Y. (Eds.), Toxic Phytoplankton Blooms in the Sea. Elsevier, Amsterdam, pp. 59-65.

Fraga, S., Bravo, I., Delgado, M., Franco, J.M., Zapata, M., 1995. Gyrodinium impudicum sp. nov. (Dinophyceae), a non-toxic, chain-forming, red tide dinoflagellate. Phycologia 34 (6), 514-521.

Gárate-Lizárraga, I., Bustillos-Guzmán, J.J., Alonso-Rodríguez, R., Luckas, B., 2004. Comparative paralytic shellfish toxin profiles in two marine bivalves during outbreaks of Gymnodinium catenatum (Dinophyceae) in the Gulf of California. Mar. Pollut. Bull. 48 (3), 397-402.

Godhe, A., Karunasagar, I., Karlson, B., 2000. Dinoflagellate cysts in recent marine sediments from SW India. Bot. Mar. 43 (1), 39-48.

Godhe, A., Norén, F., Kuylenstierna, M., Ekberg, C., Karlson, B., 2001. Relationship between planktonic dinoflagellate abundance, cysts recovered in sediment traps and environmental factors in the Gullmar Fjord, Sweden. J. Plankton Res. 23 (9), 923-938.

Graham, H.W., 1943. Gymnodinium catenatum, a new dinoflagellate from the Gulf of California. Trans. Am. Micro. Soc. 52 (3), 259-261.

Gu, H., Liu, T., Vale, P., Luo, Z., 2013. Morphology, phylogeny and toxin profiles of Gymnodinium inusitatum sp. nov., Gymnodinium catenatum and Gymnodinium microreticulatum (Dinophyceae) from the Yellow Sea, China. Harmful Algae 28, 97-107.

Gu, H., Luo, Z., Mertens, K.N., Price, A.M., Turner, R.E., Rabalais, N.N., 2015. Cyst-motile stage relationship, morphology, ultrastructure, and molecular phylogeny of the gymnodinioid dinoflagellate Barrufeta resplendens comb. nov., formerly known as Gyrodinium resplendens, isolated from the Gulf of Mexico. J. Phycol. 51 (5), 990-999.

Guillard, R.R.L., 1973. Division rates. In: Stein, J.R. (Ed.), Handbook of Phycological Methods: Culture Methods and Growth Measurements. Cambridge University Press, Cambridge, pp. 289-311.

Guillard, R.R.L., Ryther, J.H., 1962. Studies on marine planktonic diatoms. I. Cyclotella nana Hustedt and Detonula confervacea Cleve. Can. J. Microbiol. 8 (2), 229-239.

Hallegraeff, G.M., Steffensen, D.A., Wetherbee, R., 1988. Three estuarine Australian dinoflagellates that can produce paralytic shellfish toxins. J. Plankton Res. 10 (3), 533-541.

Hallegraeff, G.M., Blackburn, S.I., Doblin, M.A., Bolch, C.J.S., 2012. Global toxicology, ecophysiology and population relationships of the chainforming PST dinoflagellate Gymnodinium catenatum. Harmful Algae 14, 130-143.

Hallegraeff, G.M., Fraga, S., 1998. Bloom dynamics of the toxic dinoflagellate Gymnodinium catenatum, with emphasis on Tasmanian and Spanish coastal waters. In: Anderson, D., Cembella, A.D., Hallegraeff, G.H. (Eds.), Physiological Ecology of Harmful Algal Blooms. Springer Verlag, Heidelberg, pp. 59-80.

Hallegraeff, G.M., Mccausland, M.A., Brown, R.K., 1995. Early warning of toxic dinoflagellate blooms of Gymnodinium catenatum in southern Tasmanian waters. J. Plankton Res. 17 (6), 1163-1176. 
Hansen, G., Daugbjerg, N., Henriksen, P., 2000. Comparative study of Gymnodinium mikimotoi and Gymnodinium aureolum, comb. nov.(= Gyrodinium aureolum) based on morphology, pigment composition, and molecular data. J. Phycol. 36 (2), 394-410.

Holmes, M.J., Bolch, C.J.S., Green, D.H., Cembella, A.D., Teo, S.L.M., 2002. Singapore isolates of the dinoflagellate Gymnodinium catenatum (Dinophyceae) produce a unique profile of paralytic shellfish poisoning toxins. J. Phycol. 38 (1), 96-106.

Jiao, X., Xu, H., Hua, W., Sheng, J., 2010. The red tide organisms in Haizhou Bay. J. Aquacult. 31 (5), 25-29 (in Chinese).

John, U., Litaker, R.W., Montresor, M., Murray, S., Brosnahan, M.L., Anderson, D.M., 2014. Formal revision of the Alexandrium tamarense species complex (Dinophyceae) taxonomy: The introduction of five species with emphasis on molecular-based (rDNA) classification. Protist 165 (6), 779-804.

Joyce, L.B., 2004. Dinoflagellate cysts in recent marine sediments from Scapa Flow, Orkney, Scotland. Bot. Mar. 47 (3), 173-183.

Kon, N.F., Teng, S.T., Hii, K.S., Yek, L.H., Mujahid, A., Lim, H.C., Lim, P.T., Leaw, C.P., 2015. Spatial distribution of toxic Alexandrium tamiyavanichii (Dinophyceae) in the southeastern South China Sea-Sulu Sea: a molecular-based assessment using real-time quantitative PCR (qPCR) assay. Harmful Algae 50, 8-20.

Lirdwitayaprasit, T., Panuksubaksul, D., Takata, Y., Sato, S., Kodama, M., Fukuyo, Y., 2008. Occurrence of Gymnodinium catenatum in the Gulf of Thailand. Mar. Res. Indones. 33 (1), 87-89.

Lu, S., Hodgkiss, I.J., 2004. Harmful algal bloom causative collected from Hong Kong waters. Hydrobiologia 512, 231-238.

Luo, Z., Hu, Z., Tang, Y., Mertens, K.N., Leaw, C.P., Lim, P.T., Teng, S.T., Wang, L., Gu, H., 2018. Morphology, ultrastructure and molecular phylogeny of Wangodinium sinense gen. et sp. nov. (Gymnodiniales, Dinophyceae) and revisiting of Gymnodinium dorsalisulcum and Gymnodinium impudicum. J. Phycol. 54 (5), 744-761.

Matsuoka, K., Fukuyo, Y., 1994. Geographical distribution of the toxic dinoflagellate Gymnodinium catenatum Graham in Japanese coastal waters. Bot. Mar. 37 (6), 495-504.

Mcminn, A., Hallegraeff, G.M., Thomson, P., Jenkinson, A.V., Heijnis, H., 1997. Cyst and radionucleotide evidence for the recent introduction of the toxic dinoflagellate Gymnodinium catenatum into Tasmanian waters. Mar. Ecol. Prog. Ser. 161 (1), 165-172.

Moestrup, Ø., Hakanen, P., Hansen, G., Daugbjerg, N., Ellegaard, M., 2014. On Levanderina fissa gen. \& comb. nov. (Dinophyceae)(syn. Gymnodinium fissum, Gyrodinium instriatum, Gyr. uncatenum), a dinoflagellate with a very unusual sulcus. Phycologia 53 (3), 265-292.

Moita, M.T., Amorim, A., 2001. The relevance of Gymnodinium catenatum (Dinophyceae) over-wintering planktonic population vs. cysts as seedbanks for the local development of toxic blooms off Western Iberia. In: Garcés, E., Zingone, A., Montresor, M. Reguera, B., Dale, B. (Eds.), LIFEHAB-life Histories of Microalgal Species Causing Harmful Blooms. European Commission Directorate General Science, Research and Development, Barcelona, pp. 87-89.

Morey-Gaines, G., 1982. Gymnodinium catenatum Graham (Dinophyceae): morphology and affinities with armoured forms. Phycologia 21 (2), 154-163.

Morquecho, L., Lechuga-Devéze, C.H., 2004. Dinoflagellate cysts in recent sediments from Bahía Concepción, Gulf of California. Bot. Mar. 46 (2), 132-141.

Negri, A.P., Bolch, C.J.S., Geier, S., Green, D.H., Park, T.-G., Blackburn, S.I., 2007. Widespread presence of hydrophobic paralytic shellfish toxins in Gymnodinium catenatum. Harmful Algae 6 (6), 774-780.

Negri, A.P., Bolch, C.J.S., Blackburn, S.I., Dickman, M., Llewellyn, L.E., Mendez, S., 2001. Paralytic shellfish toxins in Gymnodinium catenatum strains from six countries. In: Hallegraeff, G.M., Blackburn, S.I., Bolch, C.J.S., Lewis, R.J. (Eds.), Harmful Algal Blooms. Intergovernmental Oceanographic Commission of UNESCO, Paris, pp. 210-213.
Oh, S.J., Matsuyama, Y., Ho, Y.Y., Miyamura, K., Geun, C.C., Yang, H.-S., Kang, I.J., 2010. Comparative analysis of paralytic shellfish toxin content and profile produced by dinoflagellate Gymnodinium catenatum isolated from Inokushi Bay, Japan. J. Fac. Agric. Kyushu Univ. 55, 47-54.

Oshima, Y., Bolch, C.J.S., Hallegraeff, G.M., 1992. Toxin composition of resting cysts of Alexandrium tamarense (Dinophyceae). Toxicon 30 (12), 1539-1544.

Oshima, Y., Hasegawa, M., Yasumoto, T., Hallegraeff, G.M, Blackburn, S.I, 1987. Dinoflagellate Gymnodinium catenatum as the source of paralytic shellfish toxins in Tasmanian shellfish. Toxicon 25 (10), 1105-1111.

Oshima, Y., Singh, H.T., Fukuyo, Y., Yasumoto, T., 1982. Identification and toxicity of the resting cysts of Protogonyaulax found in Ofunato bay. Bull. Jap. Soc. Sci. Fish 48, 1303-1305.

Park, T.G., Kim, C.H., Oshima, Y., 2004. Paralytic shellfish toxin profiles of different geographic populations of Gymnodinium catenatum (Dinophyceae) in Korean coastal waters. Phycol. Res. 52 (3), 300-305.

Pospelova, V., Chmura, G.L., Boothman, W.S., Latimer, J.S., 2002. Dinoflagellate cyst records and human disturbance in two neighboring estuaries, New Bedford Harbor and Apponagansett Bay, Massachusetts (USA). Sci. Total Environ. 298 (1), 81-102.

Pospelova, V., Kim, S.-J., 2010. Dinoflagellate cysts in recent estuarine sediments from aquaculture sites of southern South Korea. Mar. Micropaleontol. 76 (1), 37-51.

Qi, Y., Hong, Y., Zheng, L., David, K., Donald, M.A., 1996. Dinoflagellate cysts from recent marine sediments of the South and East China Seas. Asian Mar. Biol. 13, 87-103.

Rees, A.J.J., Hallegraeff, G.M., 1991. Ultrastructure of the toxic, chain-forming dinoflagellate Gymnodinium catenatum (Dinophyceae). Phycologia 30 (1), 90-105.

Romeikat, C., Knechtel, J., Gottschling, M., 2020. Clarifying the taxonomy of Gymnodinium fuscum var. rubrum from Bavaria (Germany) and placing it in a molecular phylogeny of the Gymnodiniaceae (Dinophyceae). Syst. Biodivers. 18 (2), $102-115$.

Satta, C.T., Anglès, S., Garcés, E., Lugliè, A., Padedda, B.M., Sechi, N., 2010. Dinoflagellate cysts in recent sediments from two semi-enclosed areas of the Western Mediterranean Sea subject to high human impact. Deep-Sea Res. Pt II 57 (3-4), 256-267.

Silva, T., Caeiro, M.F., Costa, P.R., Amorim, A., 2015. Gymnodinium catenatum Graham isolated from the Portuguese coast: Toxin content and genetic characterization. Harmful Algae 48, 94-104.

Smith, K.F., De, S.M., Adamson, J., Rhodes, L.L., 2014. Rapid and accurate identification by real-time PCR of biotoxin-producing dinoflagellates from the family Gymnodiniaceae. Mar. Drugs 12 (3), 1361.

Wang, N., Luo, Z., Mertens, K.N., McCarthy, F.M.G., Gu, L., Gu, H., 2017. Cyst-motile stage relationship and molecular phylogeny of a new freshwater dinoflagellate Gymnodinium plasticum from Plastic Lake, Canada. Phycol. Res. 65 (4), 312-321.

White, A.W., Lewis, C.M., 1982. Resting cysts of the toxic, red tide dinoflagellate Gonyaulax excavate in Bay of Fundy sediments. Can. J. Fish. Aquat. Sci 39 (8), 1185-1194.

Yamamoto, T., Oh, S.J., Kataoka, Y., 2002. Effects of temperature, salinity and irradiance on the growth of the toxic dinoflagellate Gymnodinium catenatum (Dinophyceae) isolated from Hiroshima Bay, Japan. Fish. Sci. 68 (2), 356-363.

Zhang, C., Luo, J., Li, S., 2019. Impacts of tropical Indian and Atlantic Ocean warming on the occurrence of the $2017 / 2018$ La Niña. Geophys. Res. Lett. 46 (6), 3435-3445.

Zhang, W., 2009. Effect of different Environment Factors on the Growth and Toxin Production of Toxic Dinoflagellate Gymnodinium catenatum (Master thesis). Jinan University, Guangzhou, pp. 58.

Zonneveld, K.A., Chen, L., Möbius, J., Mahmoud, M.S., 2009. Environmental significance of dinoflagellate cysts from the proximal part of the Po-river discharge plume (off southern Italy, Eastern Mediterranean). J. Sea Res. 62 (4), 189-213. 